In Cooperation with the Delaware River Basin Commission

\title{
Vulnerability of Production Wells in the Potomac- Raritan-Magothy Aquifer System to Saltwater Intrusion from the Delaware River in Camden, Gloucester, and Salem Counties, New Jersey
}

Scientific Investigations Report 2004-5096

U.S. Department of the Interior

U.S. Geological Survey 


\section{Vulnerability of Production Wells in the Potomac-Raritan-Magothy Aquifer System to Saltwater Intrusion from the Delaware River in Camden, Gloucester, and Salem Counties, New Jersey}

By Anthony S. Navoy, Lois M. Voronin, and Edward Modica

In cooperation with the

Delaware River Basin Commission

Scientific Investigations Report 2004-5096 


\title{
U.S. Department of the Interior Gale A. Norton, Secretary
}

\author{
U.S. Geological Survey \\ Charles G. Groat, Director
}

U.S. Geological Survey, Reston, Virginia: 2005

\author{
For sale by U.S. Geological Survey, Information Services \\ Box 25286, Denver Federal Center \\ Denver, CO 80225 \\ For more information about the USGS and its products: \\ Telephone: 1-888-ASK-USGS \\ World Wide Web: http://www.usgs.gov/
}

\begin{abstract}
Any use of trade, product, or firm names in this publication is for descriptive purposes only and does not imply endorsement by the U.S. Government.

Although this report is in the public domain, permission must be secured from the individual copyright owners to reproduce any copyrighted materials contained within this report.
\end{abstract}




\section{Contents}

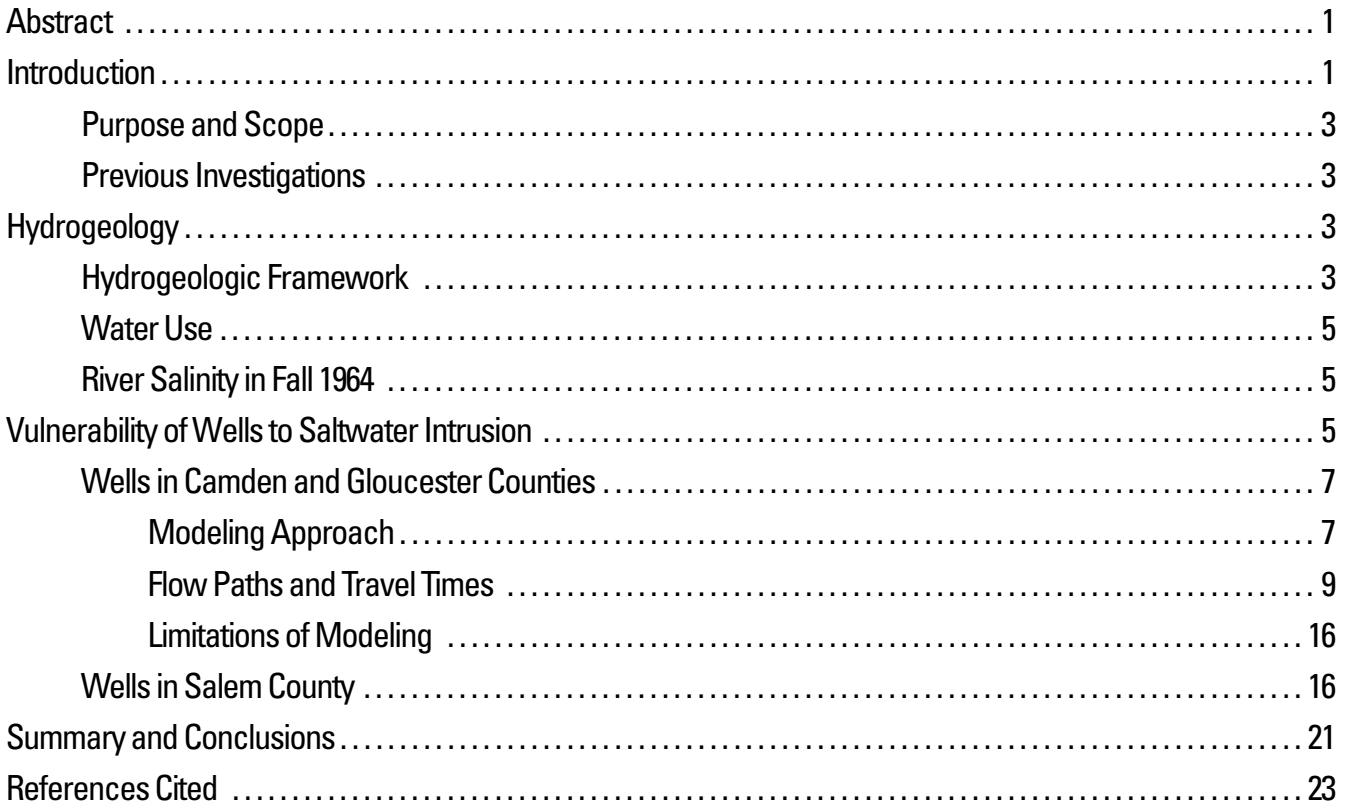

\section{Figures}

1. Map showing location of study area, outcrop of the aquifers of the Potomac-Raritan-

Magothy aquifer system, and location of wells capable of withdrawing more than

100,000 gallons per day that are within 2 miles of the Delaware River in Camden,

Gloucester, and Salem Counties, N.J.

2. Diagram showing generalized hydrogeologic section along the Delaware River, New Jersey and Pennsylvania . .

3. Map showing ground-water withddrawals from wells capable of withdrawing more than 100,000 gallons per day that are within 2 miles of the Delaware River in Camden, Gloucester, and Salem Counties, N.J., 1996 ....

4. Graph showing withdrawals from the Potomac-Raritan-Magothy aquifer system in Camden, Gloucester, and Salem Counties, N.J., 1990-96..

5-12. Maps showing -

5. (a) Location of and contributing area for wells Morris 11 and 13; (b) travel-time frequency along flow paths from the Delaware River to the wells; (c) breakthrough concentration for a single 1-month saltwater-intrusion event, and (d) breakthrough concentration for an annually recurring 1-month saltwater-intrusion event.

6. (a) Location of and contributing area for well Morris 12; (b) travel-time frequency along flow paths from the Delaware River to the well; (c) breakthrough concentration for a single 1-month saltwater-intrusion event; and (d) breakthrough concentration for an annually recurring 1-month saltwater-intrusion event.

7. (a) Location of and contributing area for wells Delair 1,2 , and 3; (b) travel-time frequency along flow paths from the Delaware River to the wells; (c) breakthrough concentration for a single 1-month saltwater-intrusion event; and (d) breakthrough concentration for an annually recurring 1-month saltwater-intrusion event.... 
8. (a) Location of and contributing area for wells Morris 7 and 10; (b) travel-time frequency along flow paths from the Delaware River to the wells; (c) breakthrough concentration for a single 1-month saltwater-intrusion event; and (d) breakthrough concentration for an annually recurring 1-month saltwater-intrusion event.

9. (a) Location of and contributing area for wells Morris 6, 8, and 9; (b) travel-time frequency along flow paths from the Delaware River to the wells; and (c) breakthrough concentration for a single 1-month saltwater-intrusion event ....

10. (a) Location of and contributing area for well Morris $3 A$; (b) travel-time frequency along flow paths from the Delaware River to the well; and (c) breakthrough concentration for a single 1-month saltwater-intrusion event; and (d) breakthrough concentration for an annually recurring 1-month saltwater-intrusion event.

11. (a) Location of and contributing area for wells GCWD 40,42, and 43; (b) travel-time frequency along flow paths from the Delaware River to the wells; and (c) breakthrough concentration for a single 1-month saltwater-intrusion event

12. (a) Location of and contributing area for wells RW-5, RW-6, and Mobil 47; (b) travel-time frequency along flow paths from the Delaware River to the wells; and (c) breakthrough concentration for a single 1-month saltwater-intrusion event.

13. Diagram showing generalized hydrogeologic section through Salem County, N.J............... 19

14-15. Maps showing-

14. Potentiometric surface of the Middle Potomac-Raritan-Magothy aquifer, Salem County, N.J., 1988

15. Concentration of dissolved chloride from water samples from the Middle PotomacRaritan-Magothy aquifer, Salem County, N.J., 1968-95

\section{Tables}

1. Locations of, construction data for, and withdrawals from wells capable of withdrawing more than 100,000 gallons per day that are within 2 miles of the Delaware River in Camden, Gloucester, and Salem Counties, N.J.

2. Saltwater-intrusion vulnerability characteristics of wells capable of withdrawing more than 100,000 gallons per day that are within 2 miles of the Delaware River in Camden and Gloucester Counties, N.J. 


\section{Conversion Factors and Datum}

\begin{tabular}{|c|c|c|}
\hline Multiply & By & To obtain \\
\hline \multicolumn{3}{|c|}{ Length } \\
\hline foot $(\mathrm{ft})$ & 0.3048 & meter $(\mathrm{m})$ \\
\hline mile (mi) & 1.609 & kilometer (km) \\
\hline \multicolumn{3}{|c|}{ Area } \\
\hline square mile $\left(\mathrm{mi}^{2}\right)$ & 2.590 & square kilometer $\left(\mathrm{km}^{2}\right)$ \\
\hline \multicolumn{3}{|c|}{ Flow rate } \\
\hline foot per day (ft/d) & 0.3048 & meter per day $(\mathrm{m} / \mathrm{d})$ \\
\hline cubic foot per second $\left(\mathrm{ft}^{3} / \mathrm{s}\right)$ & 0.02832 & cubic meter per second $\left(\mathrm{m}^{3} / \mathrm{s}\right)$ \\
\hline gallon per year (gal/yr) & 0.003785 & cubic meter per day $\left(\mathrm{m}^{3} / \mathrm{yr}\right)$ \\
\hline million gallons per day (Mgal/d) & 3785. & cubic meters per day \\
\hline million gallons per year (Mgal/yr) & 3785. & cubic meters per year \\
\hline
\end{tabular}

Vertical coordinate information is referenced to the North American Vertical Datum of 1988

(NAVD 88).

Horizontal coordinate information is referenced to the North American Datum of 1927 (NAD 27).

\section{ABBREVIATIONS USED IN REPORT}

$\mathrm{mg} / \mathrm{L} \quad$ milligram per liter

$\mu \mathrm{S} / \mathrm{cm} \quad$ microsiemens per centimeter at 25 degress Celsius 



\title{
Vulnerability of Production Wells in the Potomac-Raritan-Magothy Aquifer System to Saltwater Intrusion from the Delaware River in Camden, Gloucester, and Salem Counties, New Jersey
}

\author{
By Anthony S. Navoy, Lois M. Voronin, and Edward Modica
}

\section{Abstract}

The Potomac-Raritan-Magothy aquifer system is hydraulically connected to the Delaware River in parts of Camden and Gloucester Counties, New Jersey, and has more limited contact with the river in Salem County, New Jersey. The aquifer system is used widely for water supply, and 122 production wells that are permitted by the New Jersey Department of Environmental Protection to pump more than 100,000 gallons per day in the three counties are within 2 miles of the river. During drought, saltwater may encroach upstream from the Atlantic Ocean and Delaware Bay to areas where the aquifer system is recharged by induced infiltration through the Delaware River streambed. During the drought of the mid-1960's, water with a chloride concentration in excess of potability standards $(250 \mathrm{mg} / \mathrm{L}$ (milligrams per liter)) encroached into the reach of the river that recharges the aquifer system. The vulnerability of the major production wells in the area to similar saltwater encroachment in the future is a concern to water managers. This vulnerability was evaluated by investigating two scenarios: (1) a one-time recurrence of the conditions approximating those that occurred in the1960's, and (2) the recurrence of those same conditions on an annual basis.

Results of ground-water-flow simulation in conjunction with particle tracking and one-dimensional transport analysis indicate that the wells that are most vulnerable to saltwater intrusion are those in the Morris and Delair well fields in Camden County. A single 30-day event during which the concentration of dissolved chloride or sodium exceeds $2,098 \mathrm{mg} / \mathrm{L}$ or $407 \mathrm{mg} / \mathrm{L}$, respectively, in the Delaware River would threaten the potability of water from these wells, given New Jersey drinking-water standards of $250 \mathrm{mg} / \mathrm{L}$ for dissolved chloride and $50 \mathrm{mg} / \mathrm{L}$ for dissolved sodium. This chloride concentration is about six times that observed in the river during the 1960's drought. An annually occurring 1-month event during which the concentrations of dissolved chloride or sodium in the river exceeds $1,818 \mathrm{mg} / \mathrm{L}$ or $358 \mathrm{mg} / \mathrm{L}$, respectively, would threaten the potability of water from these wells. Wells outside the Morris and Delair well fields are substantially less vulnerable to the intermittent saltwater intrusion that was simulated.

\section{Introduction}

The Potomac-Raritan-Magothy aquifer system (locally referred to as the "PRM aquifer") is the primary source of potable water in southern New Jersey, especially in the Camden area. The outcrop of the aquifer system in southern New Jersey coincides with the course of the Delaware River, as shown in figure 1. Production wells near the river may derive part of their recharge from induced infiltration of river water (Navoy and Carleton, 1995). For a given well, the amount of recharge that originates in the river depends largely on the distance of the well from the river, assuming that other factors such as degree of confinement are equal. During drought, the lack of rainfall in the Delaware River Basin results in a decrease in the freshwater flow of the river. The lower reach of the Delaware River, downstream from Trenton, N.J., is tidal; river water is progressively more saline with proximity to the Atlantic Ocean. Any decrease in the freshwater flow of the river is offset by an upstream movement, or encroachment, of saltwater from the ocean into parts of the river that otherwise contain freshwater. This encroachment could allow saltwater to infiltrate into the aquifer system and subsequently flow toward production wells. Water managers are concerned that a severe drought could result in a degradation of the quality of ground water pumped from production wells near the river as a result of the intrusion of saltwater into the aquifer system. The possible effects of any potential rise in sea level amplify these concerns.

Storage reservoirs have been built in the upper Delaware River Basin to augment streamflow during drought to help prevent saltwater from moving upstream. The determination of the vulnerability of production wells near the river to saltwater intrusion is essential for the purposes of refining water-management policy to protect potable water supplies in the Delaware River Basin. The reach of the river that is intermittently exposed to saltwater is the riverfront of Camden, Gloucester, and Salem Counties. Generally, wells that are closest to the river in that reach and have large rates of withdrawal are those that are most vulnerable to saltwater intrusion. Because the factors differ from well to well that affect the amount of induced infiltration captured, individual wells must be evaluated to determine their 


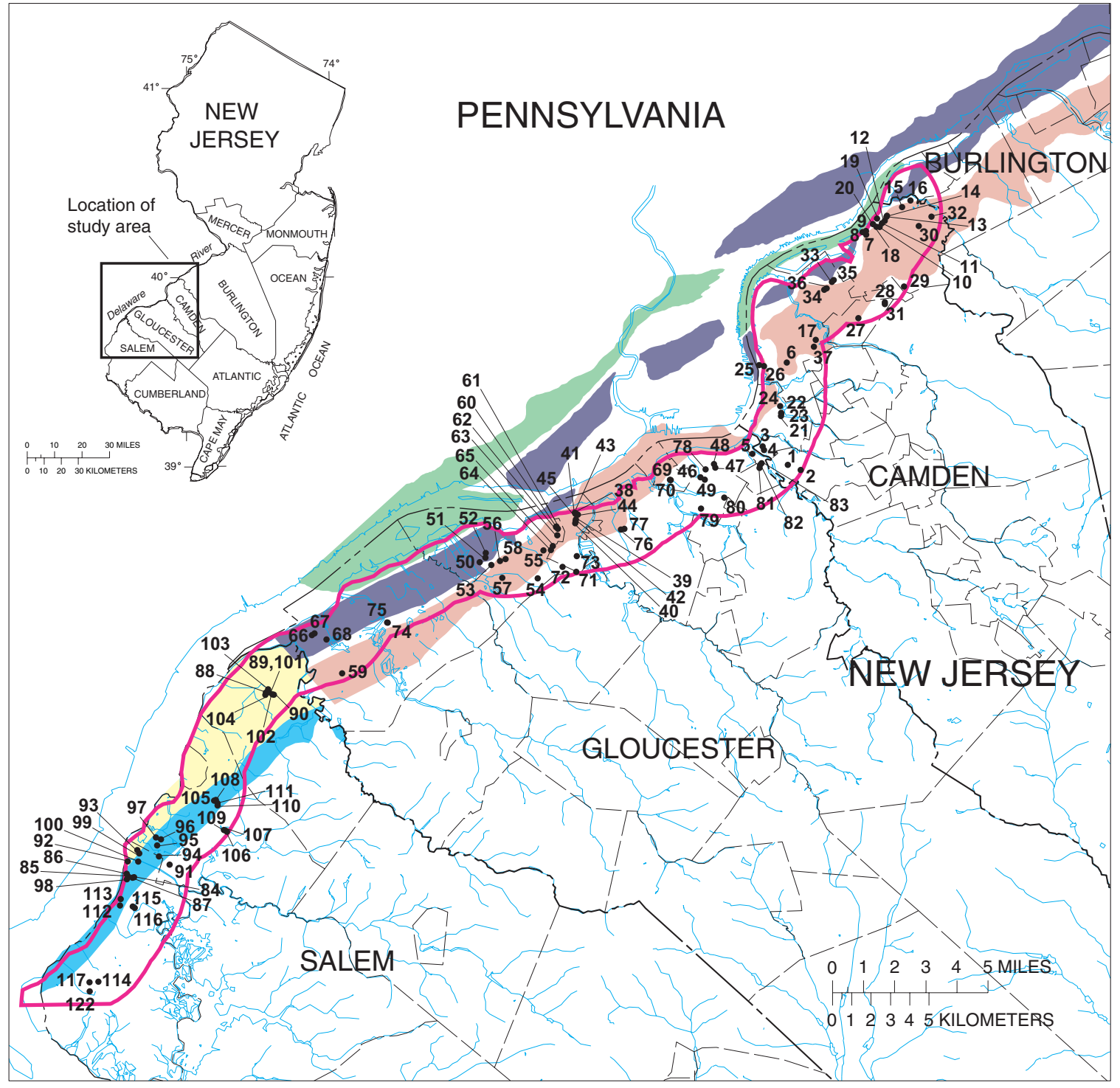

EXPLANATION

Hydrogeologic unit (Navoy and Carleton, 1995) (Gloucester, Camden, and Burlington Counties)

Outcrop area of the Upper Potomac-Raritan-Magothy aquifer

Outcrop area of the Middle Potomac-Raritan-Magothy aquifer Outcrop area of the Lower Potomac-Raritan-Magothy aquifer
Geologic unit (U.S. Geological Survey, 1967) (Salem County)

Outcrop area of the Magothy Formation

Outcrop area of the Potomac Group and Raritan Formation

Boundary of the Delaware River buffer zone (within 2 miles of the Delaware River)

117. Well location--Number shown is map number in table 2

Figure 1. Location of study area, outcrop of the aquifers of the Potomac-Raritan-Magothy aquifer system, and location of wells capable of withdrawing more than 100,000 gallons per day that are within 2 miles of the Delaware River in Camden, Gloucester, and Salem Counties, N.J. 
vulnerability to saltwater intrusion based on factors such as withdrawal rate, distance to the river, and local configuration of the aquifer system.

In this report, the term "encroachment" is used to refer to saltwater movement in the Delaware River (the surface-water system), whereas the term "intrusion" is used to refer to saltwater movement in the aquifers (ground-water system). This distinction facilitates the concurrent discussion of both processes when necessary.

\section{Purpose and Scope}

This report presents the results of an investigation of the vulnerability of production wells to contamination from induced infiltration of saltwater containing high concentrations of chloride and sodium from the Delaware River into the Potomac-Raritan-Magothy aquifer system, as might be expected during severe drought conditions. Wells completed in the aquifer system that are capable of withdrawing more than $100,000 \mathrm{gal} / \mathrm{d}$, and that are within 2 miles of the Delaware River, are the focus of the study. The study area is limited to Camden, Gloucester, and Salem Counties, N.J., because management of water-storage reservoirs in the upper Delaware River Basin potentially can affect the salinity of the river in these three counties. Production wells in the counties upstream from the study area, such as Burlington and Mercer, were not included in the investigation because they were not affected by the 1960's drought. The drought experienced in the Northeastern United States in the 1960's (1963-66) is popularly considered to be the most severe on record. Production wells in Salem County near tidal creeks that are tributary to the Delaware River and are completed in aquifers other than the Potomac-RaritanMagothy aquifer system were also not investigated. The assessment of ground-water conditions that may result from saltwater intrusion from the Delaware River does not include the determination of the likelihood of drought or of low freshwater flows in the river.

\section{Previous Investigations}

Several studies of the ground-water resources adjacent to the Delaware River in New Jersey have been conducted. Those that are most relevant to the current study are summarized here.

Navoy and Carleton (1995) developed a flow model that simulates the connection between the Potomac-Raritan-Magothy aquifer system and the Delaware River. That model provides the basis for the analyses done in this report. Navoy (1991) outlines the use of a flow model with particle tracking to test ground-water vulnerability to saltwater intrusion from the river. Simulations were conducted for five wells on the basis of 1980 's water use. Lennon and others (1986) examine chloride concentrations in ground water during the 1960's drought and discuss the potential for saltwater intrusion due to sea-level rise.

The hydrogeology of the New Jersey Coastal Plain is described in several reports. Zapecza (1989) summarizes the hydrogeologic framework of these sediments. Duran (1986) used surface geophysical methods to determine the distribution and thickness of the riverbed sediments. Lacombe and Rosman (1997), Rosman and Lacombe (1995), Eckel and Walker (1986), and Walker (1983) provide potentiometric-surface data for the Coastal Plain aquifers, including the Potomac-RaritanMagothy aquifer system, at 5-year intervals starting in 1978. Camp Dresser and McKee, Inc. (1984a, 1984b, and 1987), provide information on the ground-water-flow system and water management in the area, the connection of the aquifer system to the river, and the saltwater intrusion that occurred in the 1960's.

\section{Hydrogeology}

A conceptual understanding of the hydrogeology of the Potomac-Raritan-Magothy aquifer system was developed on the basis of the results of the previous investigations. The framework of the aquifer system, the withdrawal stresses on the system (water use), and saltwater encroachment up the Delaware River and intrusion into the aquifer system during the 1960's drought, historically the most severe, are described below and are used as the basis for the vulnerability analysis.

\section{Hydrogeologic Framework}

The Potomac-Raritan-Magothy aquifer system is part of a southeastward-dipping wedge of Coastal Plain sediments composed of gravels, sands, silts, and clays that range in age from Cretaceous to Holocene (Zapecza, 1989). The aquifer system, which consists primarily of fluvial-marginal marine sands and gravels that are the oldest of these deposits, overlies the preCretaceous crystalline bedrock. The aquifer system is differentiated locally into three components--the Upper, Middle, and Lower aquifers. Intervening confining units, generally composed of clay and silt, separate these aquifers. The orientation of the aquifer system beneath the Delaware River in the Camden area is shown in figure 2.

About $90 \mathrm{Mgal} / \mathrm{d}$ per day is withdrawn from the aquifer system through wells in Camden, Gloucester, and Salem Counties (Hoffman and Lieberman, 2000). These withdrawals have caused a large cone of depression in the potentiometric surface (Lacombe and Rosman, 1997), and water levels in some parts of the aquifer system are below sea level. Because production wells are near the river, the reach in the vicinity of Camden provides substantial recharge to the aquifer. The amount of recharge leaking from the river would be difficult to measure directly. Qualitative analysis of ground-water levels near the river does not provide the means to distinguish between river leakage and recharge from the outcrop as the source of water to wells. A ground-water-flow model was therefore used to estimate the magnitude and extent of river leakage, and the relative importance of river leakage, recharge from the outcrop area, and flow from adjacent parts of the aquifer. This information is needed to determine the vulnerability of wells to saltwater intrusion from the river. 


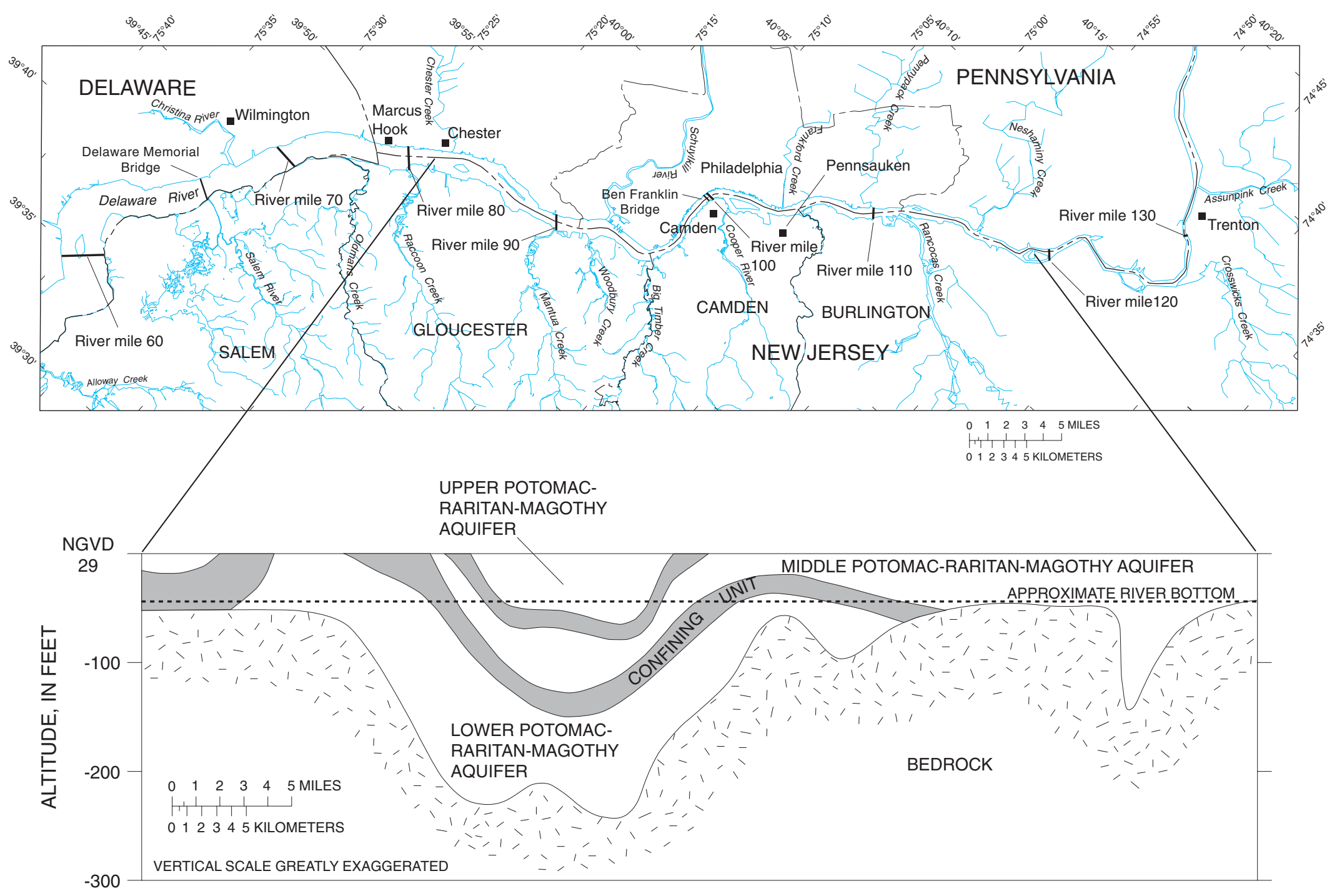

Figure 2. Generalized hydrogeologic section along the Delaware River, New Jersey and Pennsylvania. 


\section{Water Use}

A water-use and well database was compiled from information in New Jersey Department of Environmental Protection (NJDEP) files. The database consisted of water-use data for permitted wells (capable of withdrawing more than 100,000 gal/d) from 1996, the most recent year for which withdrawal information was available by individual well at the time of the compilation. Wells within $2 \mathrm{mi}$ of the river in Camden, Gloucester, and Salem Counties were identified from these data. Withdrawal data for and construction characteristics of these wells are listed in table 1 (at end of report); the wells are categorized by the magnitude of withdrawals in figure 3 . Total water use in 1996 in the 2-mi-wide, three-county area was about $12,220 \mathrm{Mgal} / \mathrm{yr}(33.5 \mathrm{Mgal} / \mathrm{d})$.

\section{River Salinity in Fall 1964}

The drought of the early to mid-1960's in the northeastern United States resulted in a period of low freshwater discharge in the Delaware River. During November and December 1964, the saltwater interface in the river, which normally is in the vicinity of Wilmington, Delaware, encroached upriver into the Camden area. The saltwater then was drawn into the Potomac-RaritanMagothy aquifer system as induced infiltration from the river (Lennon and others, 1986). This intrusion of saline water into the aquifer system provides verification that the river and aquifer are hydraulically connected and that future saltwater-intrusion events may threaten the potability of ground-water supplies.

The Delaware River reach under consideration is affected by tides, and chloride concentrations vary through each cycle. Chloride concentration is related to specific conductance. The specific conductance of water in the Delaware River at the Benjamin Franklin Bridge in Philadelphia (station 01467200, river mile 100.16, fig. 2) typically is less than $500 \mu \mathrm{S} / \mathrm{cm}$ (Kolva and others, 1989). The maximum recorded specific conductance during November 1964 was slightly less than $1,500 \mu \mathrm{S} / \mathrm{cm}$ (U.S. Geological Survey, 1965, p. 43). For approximately 21 days, from November 16 th to December 5 th, the daily maximum and daily mean specific conductance of the river water exceeded $1,000 \mu \mathrm{S} / \mathrm{cm}$. On the basis of a simple statistical correlation of monthly measurements of chloride concentrations and specific conductance of Delaware River water (U.S. Geological Survey, 1965, p. 42), the concentrations of dissolved chloride in water with specific conductances of 1,500 and $1,000 \mu \mathrm{S} / \mathrm{cm}$ were approximately 300 and $200 \mathrm{mg} / \mathrm{L}$, respectively.

The river-monitoring site at the Benjamin Franklin Bridge is in the reach of the river where induced infiltration into the Lower aquifer occurs because the substantial water-supply withdrawals have lowered ground-water levels below the river level (Gill and Farlekas, 1976, sheet 2, map showing potentiometric surface for 1968). The saltwater that flowed into the aquifer in November and December 1964 was transported toward water-supply wells near the river. The concentration of dissolved chloride in water from wells near this river reach increased most likely as a result of the intrusion of saltwater into the aquifer. Lennon and others (1986, fig. 15) show that chloride concentrations in water-supply wells increased about 15 to $25 \mathrm{mg} / \mathrm{L}$ above background levels (concentrations had been about 8 to $10 \mathrm{mg} / \mathrm{L}$ ) starting in 1965 , roughly a year after the encroachment had occurred.

\section{Vulnerability of Wells to Saltwater Intrusion}

Not all wells screened within the Potomac-Raritan-Magothy aquifer system are hydraulically connected with the Delaware River. Navoy and Carleton (1995, fig. 53) show that river water that has been induced to flow into the aquifer system is not likely to be found more than $2 \mathrm{mi}$ from the river in the Camden area. Thus, the investigation of vulnerability can be limited to this 2-mi-wide area, which is referred to in this report as the Delaware River buffer zone (fig. 1). The locations of important withdrawal wells (those with water-allocation permits from NJDEP to pump more than $100,000 \mathrm{gal} / \mathrm{yr}$ ) within the 2-miwide area are also shown in figure 1 . Wells with smaller withdrawals have very small cones of depression and are much less likely to induce recharge from the river. Therefore, they can be eliminated from consideration in this study. The wells shown in figure 1 and listed in table 1 are those that are most likely to capture water derived from induced infiltration of river water; therefore, these wells were selected for evaluation of their vulnerability to saltwater intrusion.

The Potomac-Raritan-Magothy aquifer system is a complex assemblage of multiple aquifer layers that have an irregular contact with the Delaware River, and from which many watersupply wells withdraw water. The ground-water-flow model developed by Navoy and Carleton (1995) is a tool that accounts for this complexity. The model cannot be used, however, to directly determine changes in chloride concentrations. This task can be accomplished by the use of particle tracking and concurrent, one-dimensional ground-water solute-transport analysis. In this manner, available tools can be used to assess vulnerability without the additional time and expense needed to develop an area-wide solute-transport model.

Because the ground-water-flow model of the Camden area developed by Navoy and Carleton (1995) does not include Salem County and therefore does not encompass the entire reach of the river that is within the current study area, the vulnerability of the wells in Salem County that are within 2 mi of the river was evaluated by means of other, albeit less sophisticated, methods. A comparison with simulation results for wells in Camden and Gloucester Counties, however, provided some confidence in the results of the analysis of the wells in Salem County. 


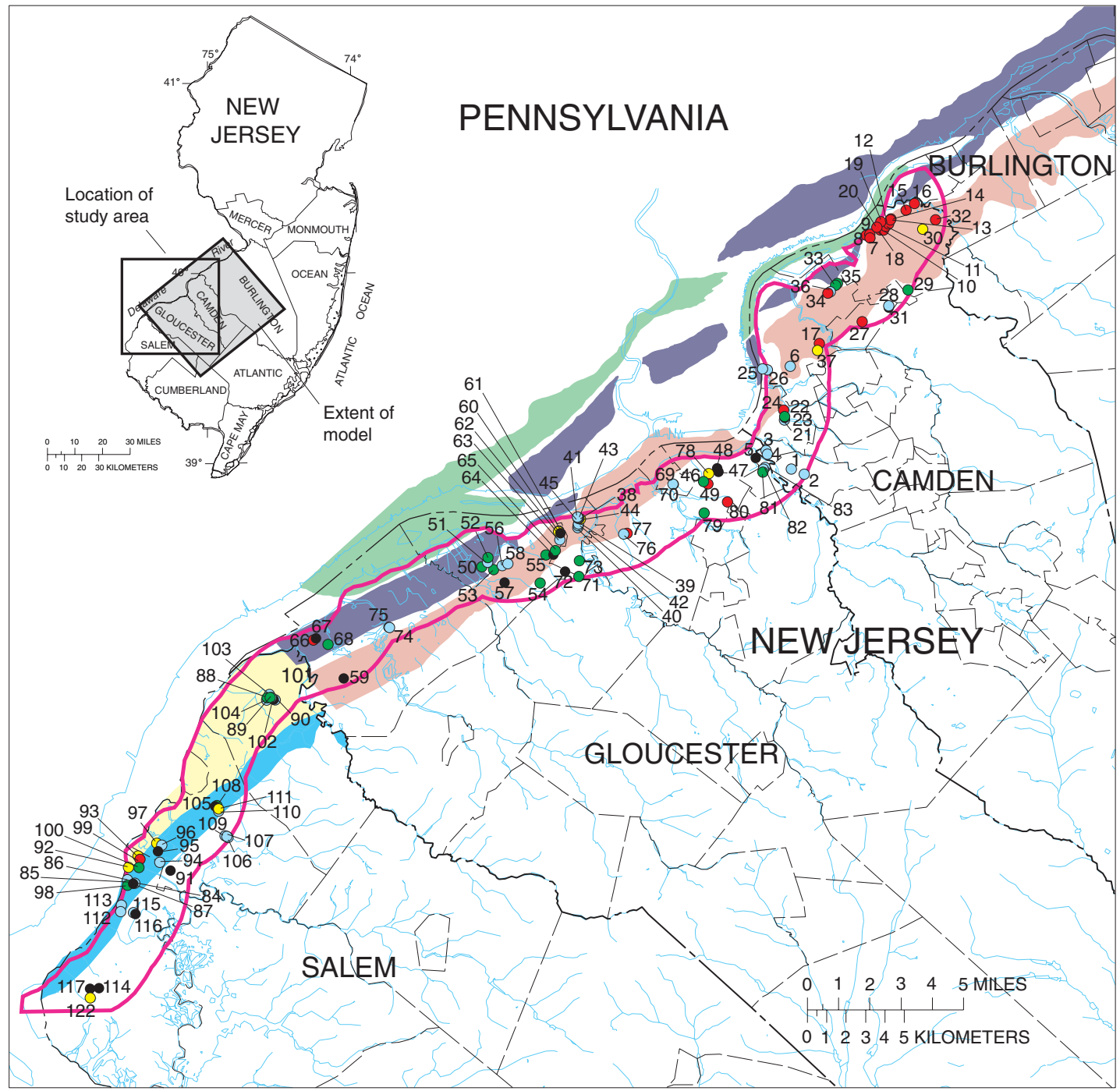

EXPLANATION

Hydrogeologic unit (Navoy and Carleton, 1995) (Gloucester, Camden, and Burlington Counties)

Boundary of the Delaware River buffer zone

Outcrop area of the Upper Potomac-Raritan-Magothy aquifer LOCATION OF WELL--Pumpage is

Outcrop area of the Middle Potomac-Raritan-Magothy aquifer

Outcrop area of the Lower Potomac-Raritan-Magothy aquifer

Geologic unit (U.S. Geological Survey, 1967) (Salem County)

Outcrop area of the Magothy Formation

Outcrop area of the Potomac Group and Raritan Formation

- Greater than 200 million gallons per year

- 100 - 200 million gallons per year

- 50 - 100 million gallons per year

0.5 - 50 million gallons per year

0 Less than 0.5 million gallons per year

Figure 3. Ground-water withdrawals from wells capable of withdrawing more than 100,000 gallons per day that are within 2 miles of the Delaware River in Camden, Gloucester, and Salem Counties, N.J., 1996. 


\section{Wells in Camden and Gloucester Counties}

\section{Modeling Approach}

The ground-water-flow model of the Potomac-RaritanMagothy aquifer system in the Camden area developed previously by Navoy and Carleton (1995) by use of MODFLOW (McDonald and Harbaugh, 1988) as a tool for water-resources managers to use in evaluation of ground-water-withdrawal management strategies was used in this analysis. Detailed information on the design and calibration of the model is available in Navoy and Carleton (1995). Because the model is used to simulate the hydraulic interaction of the aquifer system with the Delaware River and its tributaries, it can be used to determine the potential for supply wells near the river to capture water from the river. The model consists of a five-layer, quasi-threedimensional representation of the hydrogeologic units. The Upper, Middle, and Lower aquifers of the Potomac-RaritanMagothy aquifer system are represented by three model layers; the two additional model layers represent stratigraphically younger aquifers that overlie the confined parts of the PotomacRaritan-Magothy aquifer system. These aquifers are included to account for vertical boundary flow in downdip areas. Horizontal boundary flows were derived from the more coarsely discretized USGS Regional Aquifer Systems Analysis (RASA) model of the entire New Jersey Coastal Plain (Martin, 1998). A no-flow boundary represents the crystalline rocks underlying the aquifer system. The simulated aquifers were discretized hor- izontally into a variably spaced grid having 99 rows and 106 columns that is oriented approximately parallel to the Fall Line and the strike of the Potomac-Raritan-Magothy aquifer system. The extent of the model is shown in the inset map in figure 3. The smallest model cells are $880 \mathrm{ft}$ by 1,650 ft and are near the Delaware River. These dimensions allow the span of river to be covered by three or more grid cells, providing for an accurate representation of the river's morphology and of the variability of riverbed permeability. The largest cells are $2,200 \mathrm{ft}$ by $3,300 \mathrm{ft}$ and generally are in the downdip, southeastern part of the model, farther from the river. The model was calibrated to historical water-level data (Navoy and Carleton, 1995).

The potential for each of the wells to induce infiltration of river water can be determined with a particle-tracking technique. The simulated movement of hypothetical particles as they travel through the ground-water-flow field is determined as a function of time, generating path lines and time-of-travel information (Pollock, 1988).

A steady-state simulation was performed with withdrawal rates for 1996, and ground-water-flow paths were determined by use of the MODPATH particle tracker (Pollock, 1989). Effective porosity values of 0.35 for the aquifers, a typical value for sand, and 0.45 for the confining units, a typical value for clays, were used (Freeze and Cherry, 1979, p. 37). A steadystate analysis is suitable because withdrawals from the Potomac-Raritan-Magothy aquifer system in the Camden area have been fairly stable over time, as shown by the annual withdrawal data in figure 4 . Withdrawals from the aquifer system are not

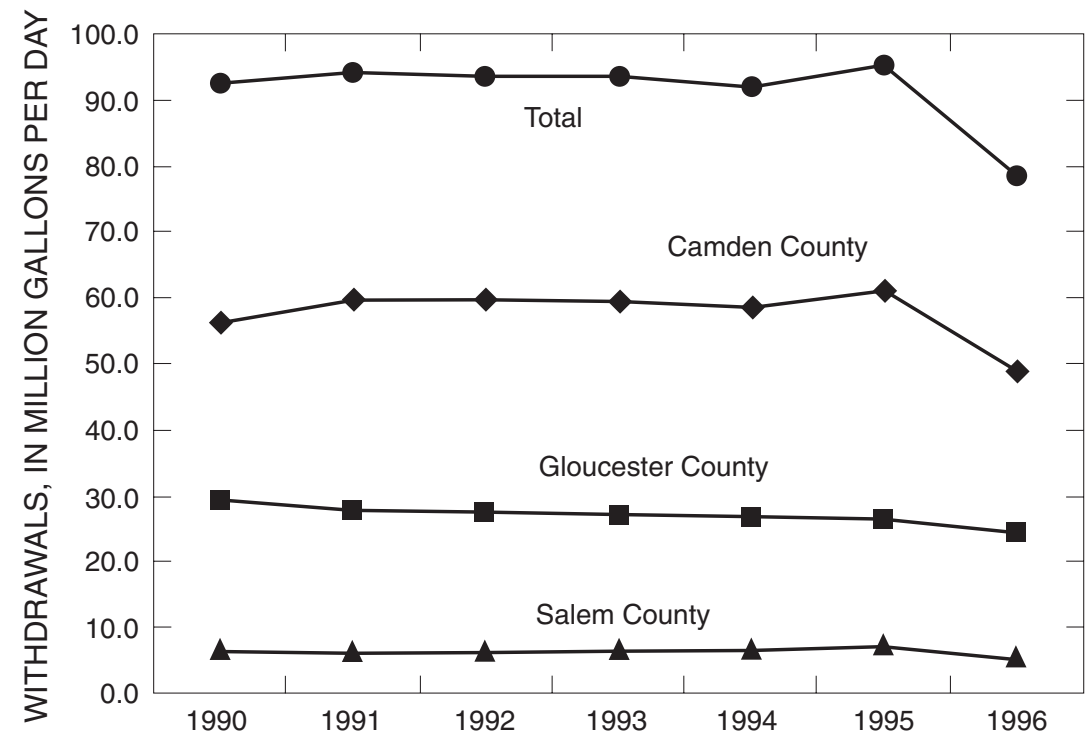

Figure 4. Withdrawals from the Potomac-Raritan-Magothy aquifer system in Camden, Gloucester, and Salem Counties, N.J., 1990-96. (From Hoffman and Lieberman, 2000, app. A, tables A4, A8, and $A 17)$ 


\section{Vulnerability of Production Wells in the Potomac Aquifer System to Saltwater Intrusion from the Delaware River, N.J.}

likely to increase substantially in the future; the NJDEP has determined that the deep cones of depression in the aquifer system are indicative of conditions approaching over-pumping, and has initiated measures to restrict or curtail future increases in withdrawals (N.J. Department of Environmental Protection, 1986; New Jersey Administrative Code, 1995). Thus, the withdrawal rates used are likely to be representative of those in the Camden area in the foreseeable future.

The particle-tracking analysis supports a one-dimensional transport analysis using the advection-diffusion equation (Javandel and others, 1984, eq. 1, p. 9) to account for dispersive processes along each calculated flow path:

$$
\frac{\partial}{\partial x}\left(D \frac{\partial C}{\partial x}\right)-\frac{\partial}{\partial x}(C v)=\frac{\partial C}{\partial t},
$$

$$
\text { where } \begin{aligned}
v & =\frac{-K}{n} \frac{\partial h}{\partial x} \\
C & =\text { solute concentration, } \\
D & =\text { dispersion coefficient, } \\
K & =\text { hydraulic conductivity } \\
x & =\text { coordinate distance } \\
v & =\text { average pore-water velocity } \\
n & =\text { effective porosity } \\
h & =\text { hydraulic head }
\end{aligned}
$$

and

$$
t=\text { time. }
$$

The velocity values needed to solve advective-diffusive transport are generated with the ground-water-flow model and particle-tracking software. A.L. Baehr (U.S. Geological Survey, written commun., 1989) developed a computer program to evaluate analytically the one-dimensional advection-diffusion equation over a semi-infinite domain in which a time-dependent input concentration boundary condition (of the first kind) is allowed by employing Duhamel's Principle (Carslaw and Jaeger, 1959, p. 30; Bear, 1979, p. 158). This approach was used to simulate the change in concentrations along flow paths and has been described in Navoy (1991, p. 113 and app. D).

The calibration of dispersivity needed for the one-dimensional transport analysis can be done with observed data. The chloride-concentration peak arrival in the wells during the mid1960's drought as shown by Lennon and others (1986, fig. 15) fall into two groups. One group, with an apparent ground-waterflow velocity of 2,000 ft/yr, shows an increase in dissolvedchloride concentration to a peak of approximately $25 \mathrm{mg} / \mathrm{L}$. The other group, with an apparent velocity of 4,000 ft/yr, also shows an increase to a peak of approximately $25 \mathrm{mg} / \mathrm{L}$. (These apparent velocities are very high for ground water; however, these are conditions close to large-capacity water-supply wells and are not representative of natural or background conditions.) Because the data are sparse, a precise indication of the peak breakthrough concentration is not possible.

A range of dispersivities was used in the one-dimensional solute-transport model to produce chloride-breakthrough curves for velocities of 2,000 and 4,000 ft/yr to determine the dispersivity that best corresponds to the observed chloride peak arrival data. If the proportion of river water pumped by the monitored water-supply wells is estimated to be about 75 percent, a dispersivity of about $100 \mathrm{ft}$ yields chloride concentrations of 0.75 times 40 and $55 \mathrm{mg} / \mathrm{L}$ ( 30 and $41 \mathrm{mg} / \mathrm{L}$ ) for 2,000 and $4,000 \mathrm{ft} / \mathrm{yr}$ velocities, respectively. These values are consistent with the magnitude and timing of the observed data (Navoy, 1991, p. 114). Gillham and Cherry (1982, p. 46) and Anderson (1979, p. 126) suggest a range of longitudinal dispersivity of 10 to $200 \mathrm{ft}$ for unconsolidated, saturated clastic aquifers. The dispersivity of $100 \mathrm{ft}$ falls within this range, lending additional confidence to the estimate.

Two drought scenarios based on 1964 conditions were examined. The first scenario represents an isolated 1-month event in which saltwater encroaches upriver to a point adjacent to the recharge area for the wells. The second scenario represents intermittent saltwater encroachment in the river that recurs regularly for a 1-month period each year.

The approach used to determine the vulnerability of each well to saltwater intrusion is as follows. For each selected well, the lengths of the ground-water-flow paths between the river and the well and the ground-water velocity along each flow path (required to solve the advective-diffusion equation) were calculated with the particle tracker. This task was accomplished by specifying an array of particles at each model cell from which ground water is withdrawn and backtracking these particles to their point of recharge. The percentage of particles that was tracked to cells representing the Delaware River provides an estimate of the fraction of water withdrawn from the well that is derived from the river. Average flow-path length and velocity were calculated for a set of flow-path classes that consist of flow paths whose travel times fall into 5-year travel-time intervals. Breakthrough-curve concentrations then were determined with the one-dimensional transport model for each flow-path class on the basis of the velocity and flow-path length determined from the particle-tracking analysis. A composite breakthrough curve for each of the two scenarios then was made for each well by combining the concentrations determined for each flow-path class, weighted by the fraction of flow to the well it represents. This composite breakthrough curve is the concentration of a conservative solute through time at the well for the flow paths originating in the river. The peak concentration from the composite breakthrough curve, mixed proportionately with the water originating from nonriver sources $(20 \mathrm{mg} / \mathrm{L}$ dissolved chloride or sodium), yields the maximum concentration expected at the well. 


\section{Flow Paths and Travel Times}

Analysis of the results obtained by use of the groundwater-flow model, particle tracker, and one-dimensional solutetransport model indicates that the wells within $2 \mathrm{mi}$ of the river in Camden and Gloucester Counties can be categorized into three groups on the basis of their vulnerability to saltwater intrusion from the Delaware River: a high-vulnerability group, a low-vulnerability group, and a group with virtually no vulnerability. Of the 122 wells located within 2 mi of the river, 83 are in Camden and Gloucester Counties (table 1). Fourteen percent of these wells are in the high-vulnerability group, 34 percent are in the low-vulnerability group, and 52 percent are in the no-vulnerability group. The results of the simulation of the two scenarios for each well are listed by vulnerability group in table 2 (at end of report).

The vulnerability categorization for each well is based on the travel time along the flow paths from the river to the well and the percent of well water derived from the river. All of the wells grouped in the low- and no-vulnerability classifications have the majority portion of their flow-path travel times in excess of 20 years. This criterion relates to a dilutive process. As travel time increases, in most cases related to increased distance from the river, the opportunity increases for dispersion and mixing to occur between water of varying flow paths that are converging at the well. For the intermittent intrusion scenarios tested, this substantially dilutes the peak concentration arriving at a well that originated at the river. For travel times longer than 20 years, simulated concentrations at such wells were much less than 1 percent of the starting concentration in the river for the intermittent intrusion scenarios tested. Additionally, the wells in the no-vulnerability classification have less than 40 percent of well water derived from the river. Correspondingly, the wells in the high-vulnerability classification have the majority portion of their flow-path travel times from the river shorter than 20 years and the majority of the water is derived from the river.

The high-vulnerability group contains only wells in the City of Camden well fields in Pennsauken. These wells generally have high withdrawal rates (200 to $500 \mathrm{Mgal} / \mathrm{yr}$ ) and are very close to the river (typically within 0.5 mile). The aquifer layer in which these wells are screened is hydraulically wellconnected with the river adjacent to the well field; therefore, it is not surprising that these wells are the most vulnerable. Some of the wells in the Camden well fields, as well as some in the other groups, are near enough to each other to be included in the same cell of the ground-water-flow model. In such cases, the pumpage is combined in the one model cell (table 2). The percentage of the pumpage from each of the wells in the group that is derived from the river, as simulated with the model, ranges from 54 to 93 percent.

Results of the simulation of the single, 1-month-duration saltwater-encroachment event indicate that a pulse of saltwater arriving at the high-vulnerability wells contained between 2 and 13 percent of the initial concentration in the river. In this type of analysis, the transport process is assumed to be conservative; that is, no significant chemical or physical reactions occur between the dissolved constituents and the aquifer materials along the flow path. For chloride, this assumption is valid. For sodium, this assumption does not include the potential for ion exchange with clay minerals, which could lower the concentration along a given flow path. Depending on the percentage of river water comprising the water pumped from the well (table 2), these data indicate that the critical concentrations in the river that would cause water in the well to be nonpotable range from 2,098 to 22,269 $\mathrm{mg} / \mathrm{L}$ for dissolved chloride and from 407 to $3,777 \mathrm{mg} / \mathrm{L}$ for dissolved sodium. These thresholds are based on the New Jersey drinking-water standard of $250 \mathrm{mg} / \mathrm{L}$ for dissolved chloride and $50 \mathrm{mg} / \mathrm{L}$ for dissolved sodium (New Jersey Administrative Code, 1989).

Results of the simulation of the annually recurring, 1-month-duration saltwater-encroachment event indicate that a pulse of saltwater arriving at the high-vulnerability wells contained between 2 and 15 percent of the initial concentration in the river. For this scenario, the critical concentrations in the river that would render the water from the well nonpotable range from 1,818 to $22,296 \mathrm{mg} / \mathrm{L}$ for dissolved chloride and from 358 to $3,777 \mathrm{mg} / \mathrm{L}$ for dissolved sodium. The thresholds in this scenario are lower than those in the previous scenario because the recurrent saltwater encroachment has an additive affect through time that increases the amount of saltwater that reaches each well.

The locations, contributing areas, and arrival-concentration data for the individual wells in the high-vulnerability group are plotted in figures 5 through 10 . These figures also indicate, by histogram, the range in travel times of the flow paths from the river to the wells. In the high-vulnerability group, most of the flow-path travel times are less than 5 years. The graphs of the concentration of conservative solute arriving at each well ("breakthrough plots"), shown in figures 5 (c and d), 6 (c and d), and 7 ( $\mathrm{c}$ and d) for the Morris 11 and 13 wells, the Morris 12 well, and the Delair wells, respectively, indicate that the peak concentration can arrive within 1 year of the encroachment event in the river. This is consistent with the observations made from the mid-1960's event (Lennon and others, 1986, fig. 15). Ground-water velocities play an important role in the mechanical dispersion of solutes, such as those in saltwater (sodium and chloride). Water withdrawn from a well has traveled along flow paths of varying lengths because the recharge, or source of water to a well, generally is distributed over a large area or reach of stream that is hydraulically connected to the aquifer. Consequently, the travel times of ground water that flows to a single well vary. Where a well is located near a source of recharge, flow paths and, therefore, travel times to the well will be relatively short. Because the solute is not transported far, mechanical dispersion is small, resulting in the movement of relatively large concentrations of solute toward the well. In contrast, ground-water-flow paths to a well that is distant from its source of water are relatively long and have long travel times. Water traveling along long flow paths has a lower average ground-water velocity, greater dispersion, and lower arrival concentration of solute at the well than water traveling along short flow paths. 

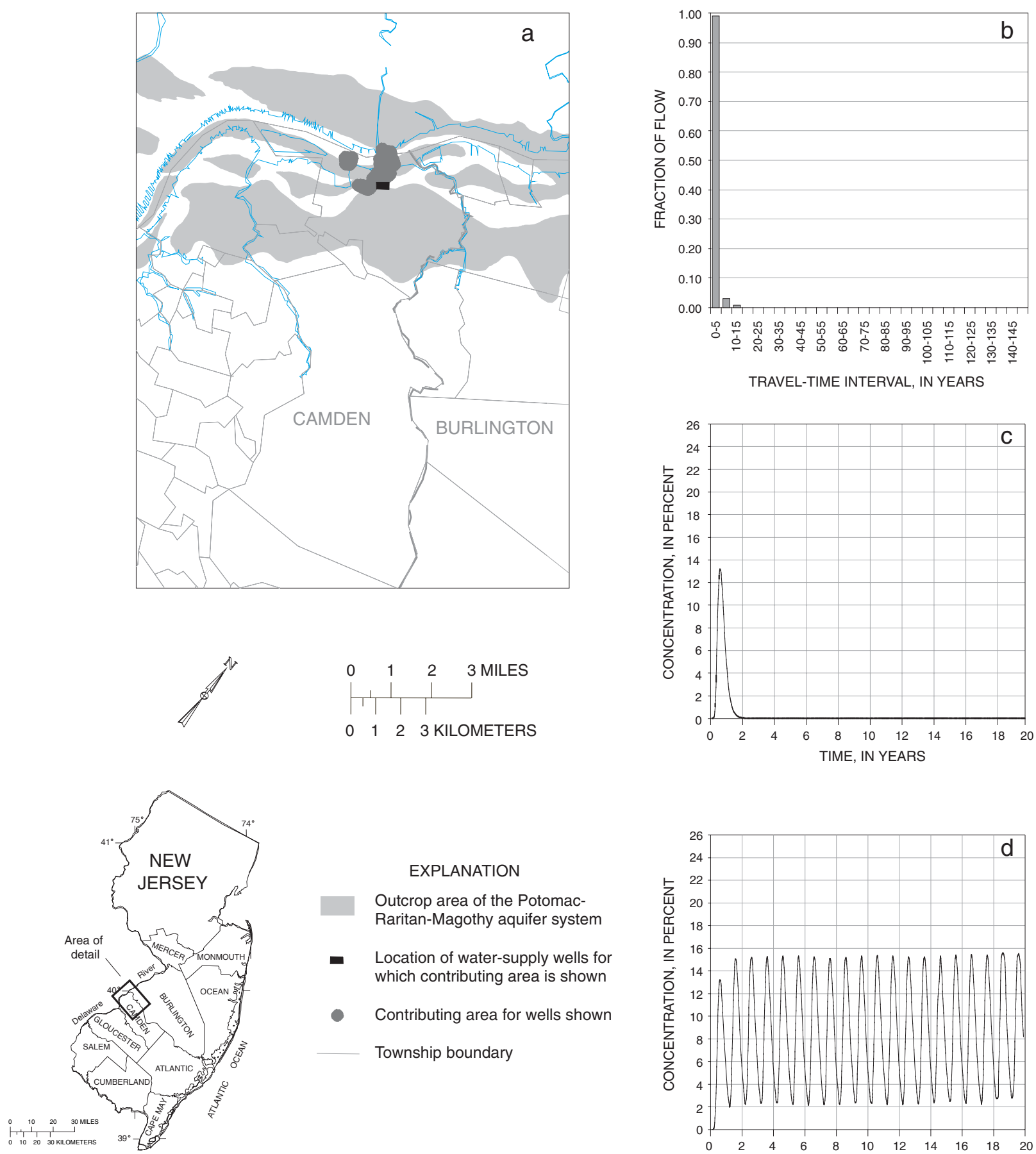

\section{EXPLANATION}

Outcrop area of the PotomacRaritan-Magothy aquifer system

- Location of water-supply wells for which contributing area is shown

- Contributing area for wells shown Township boundary

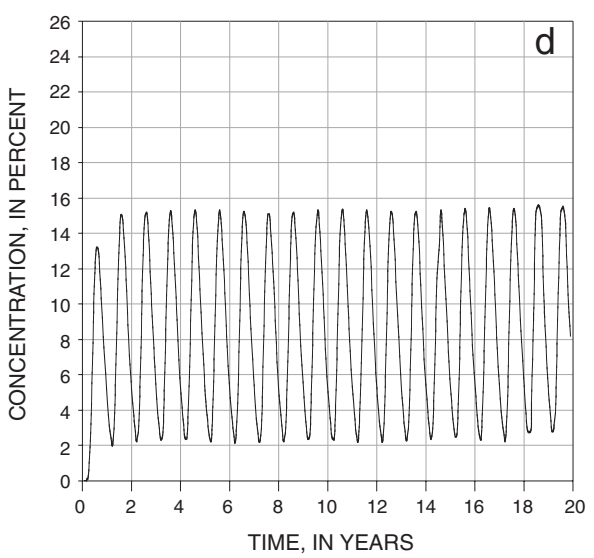

Figure 5. (a) Location of and contributing area for wells Morris 11 and 13; (b) travel-time frequency along flow paths from the Delaware River to the wells; (c) breakthrough concentration for a single 1-month saltwater-intrusion event; and (d) breakthrough concentration for an annually recurring 1-month saltwater-intrusion event. 

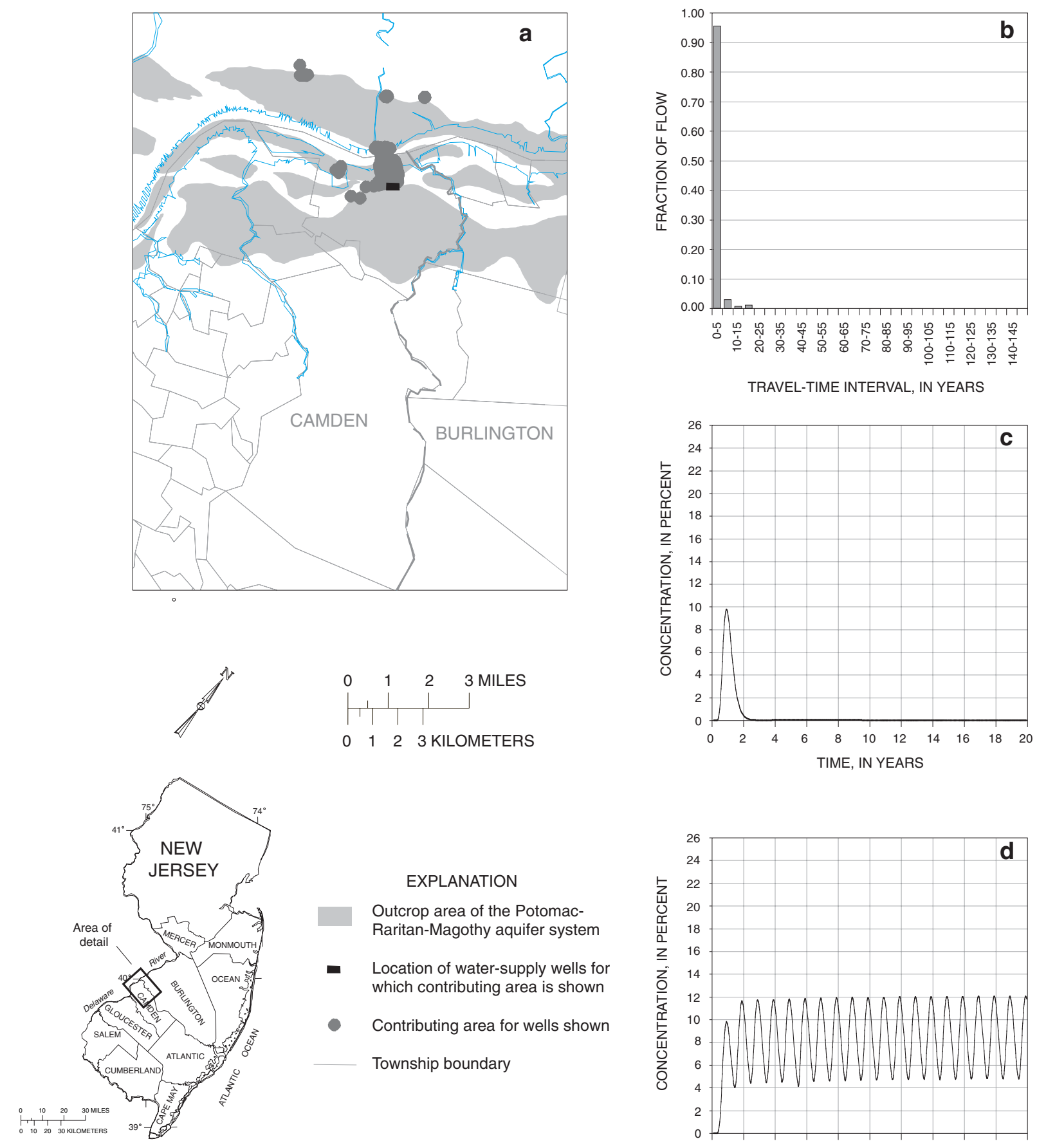

\section{EXPLANATION}

Outcrop area of the PotomacRaritan-Magothy aquifer system

- Location of water-supply wells for which contributing area is shown

- Contributing area for wells shown Township boundary

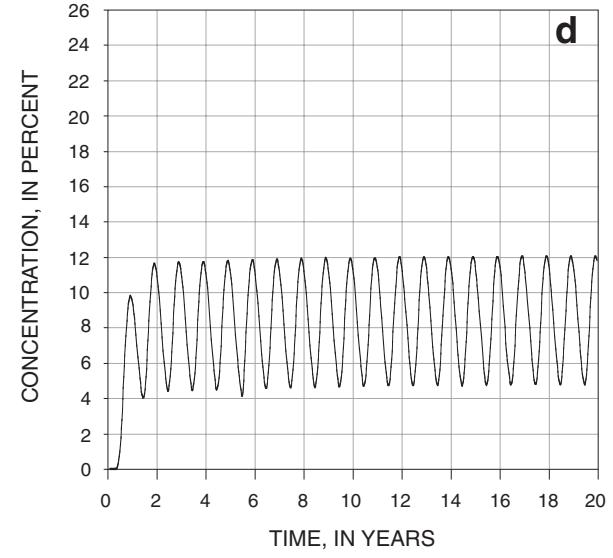

Figure 6. (a) Location of and contributing area for well Morris 12; (b) travel-time frequency along flow paths from the Delaware River to the well; (c) breakthrough concentration for a single 1-month saltwater-intrusion event; and (d) breakthrough concentration for an annually recurring 1-month saltwater-intrusion event. 

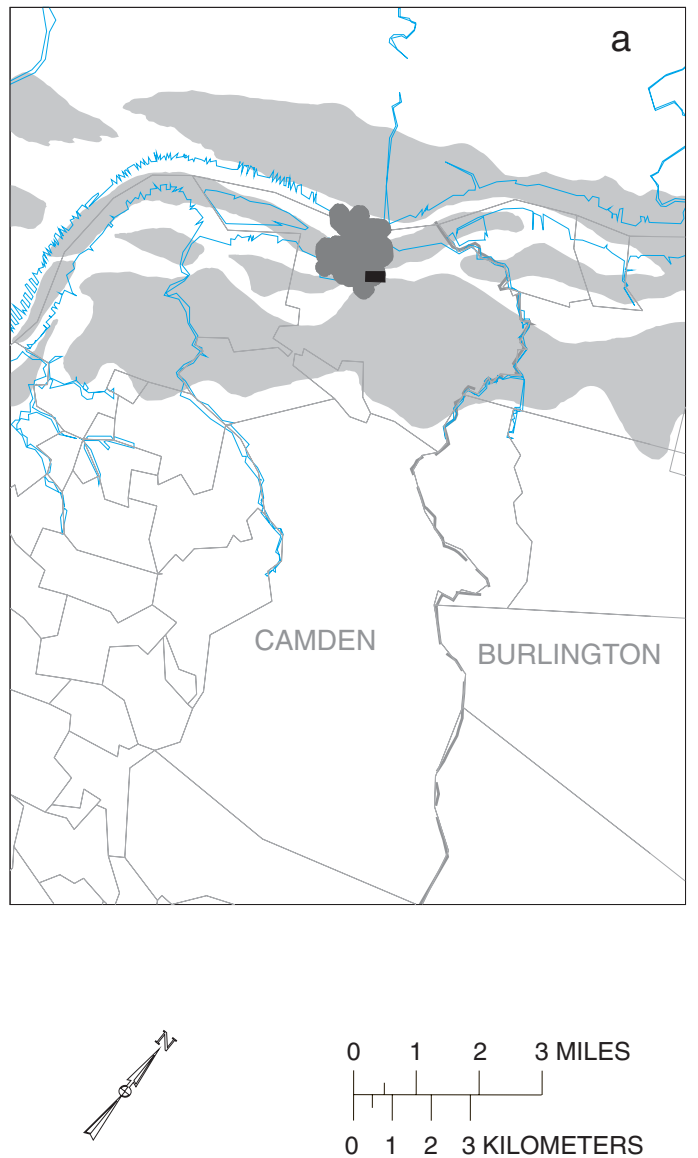

\section{EXPLANATION}

Outcrop area of the PotomacRaritan-Magothy aquifer system

- Location of water-supply wells for which contributing area is shown

- Contributing area for wells shown Township boundary

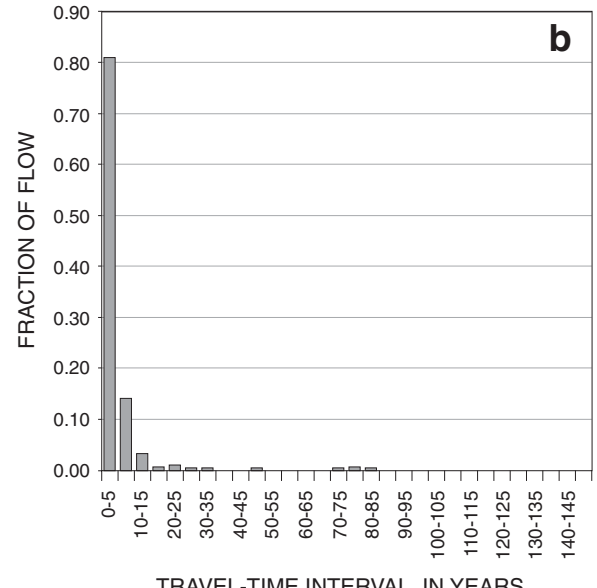

TRAVEL-TIME INTERVAL, IN YEARS
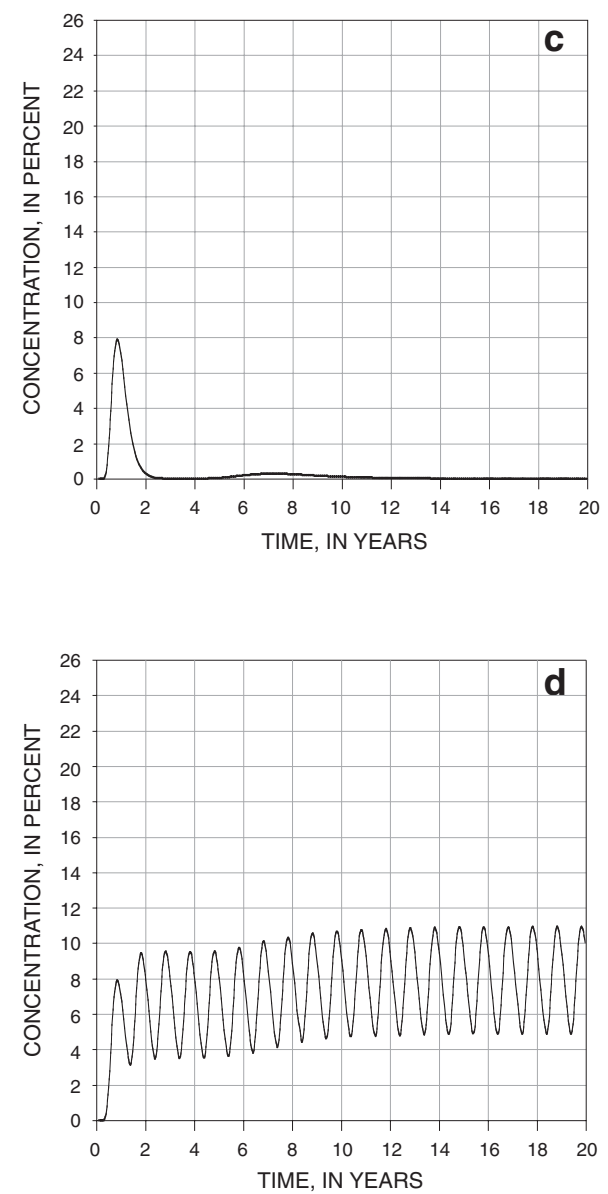

Figure 7. (a) Location of and contributing area for wells Delair 1, 2, and 3; (b) travel-time frequency along flow paths from the Delaware River to the wells; (c) breakthrough concentration for a single 1-month saltwater-intrusion event; and (d) breakthrough concentration for an annually recurring 1-month saltwater-intrusion event. 

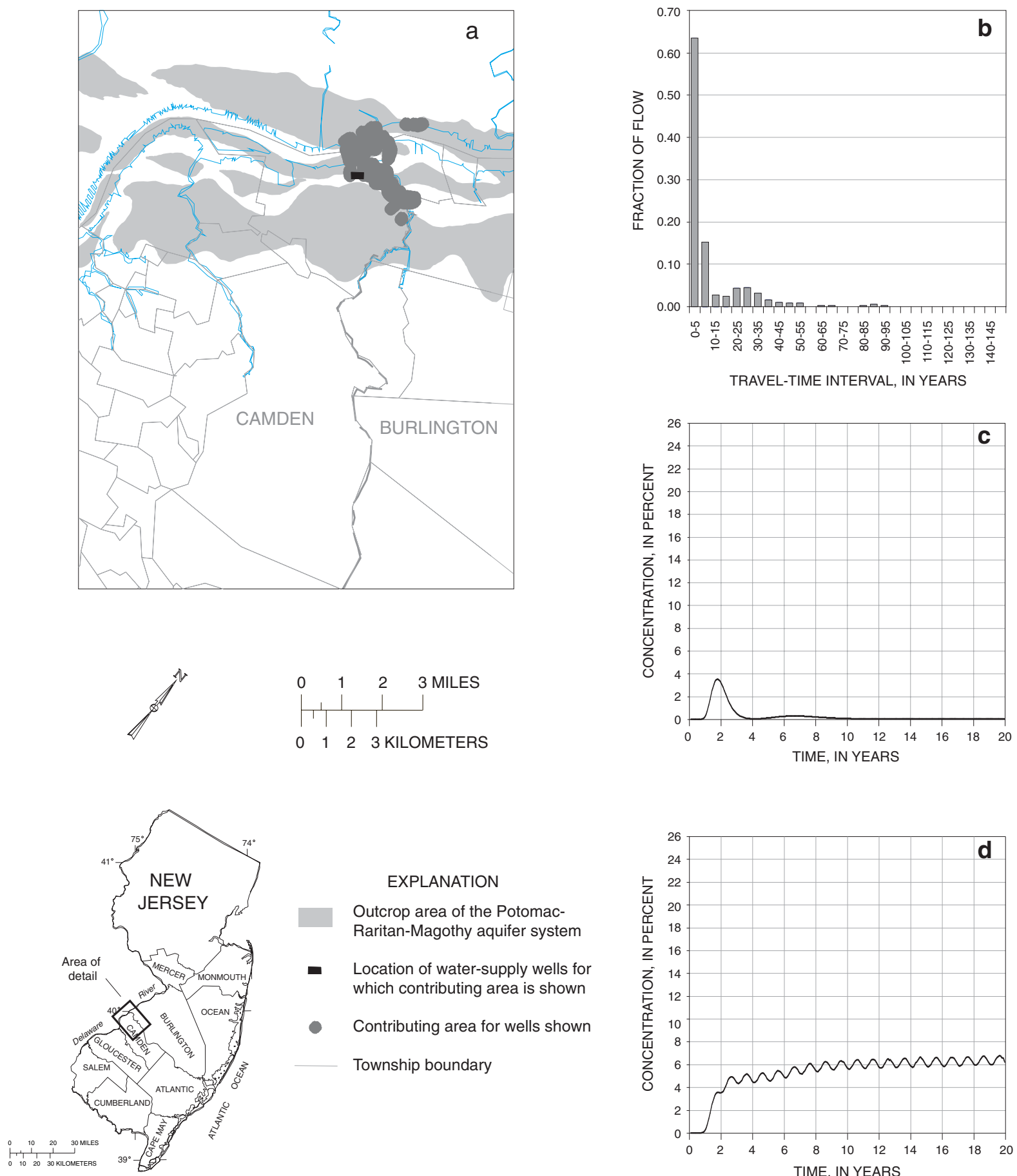

EXPLANATION

Outcrop area of the PotomacRaritan-Magothy aquifer system

- Location of water-supply wells for which contributing area is shown

- Contributing area for wells shown

Township boundary

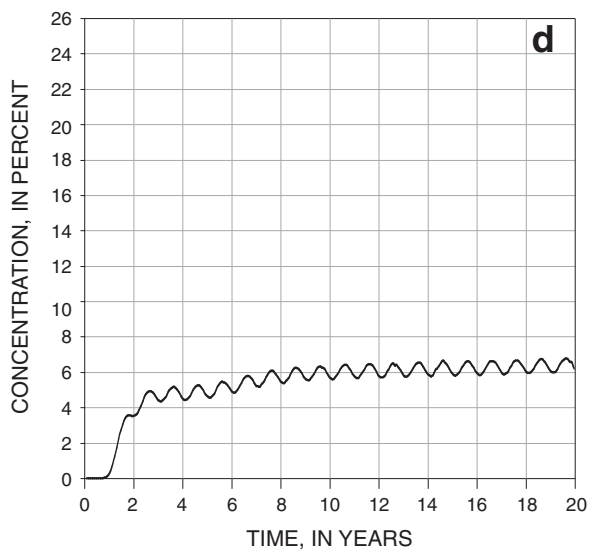

Figure 8. (a) Location of and contributing area for wells Morris 7 and 10; (b) travel-time frequency along flow paths from the Delaware River to the wells; (c) breakthrough concentration for a single 1-month saltwater-intrusion event; and (d) breakthrough concentration for an annually recurring 1-month saltwater-intrusion event. 

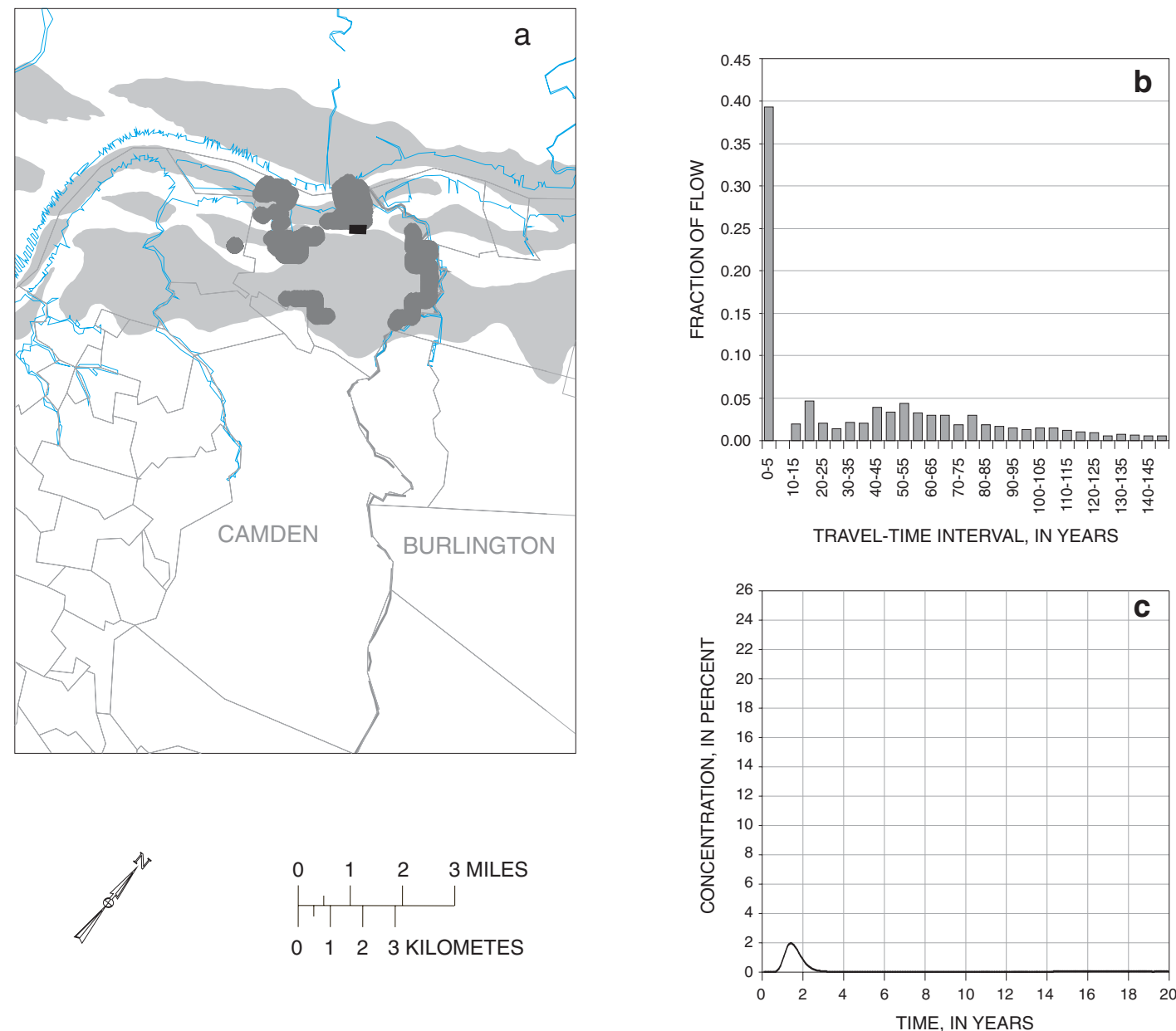

\section{EXPLANATION}

Outcrop area of the Potomac-

Raritan-Magothy aquifer system

- Location of water-supply wells for

which contributing area is shown

- Contributing area for wells shown

Township boundary

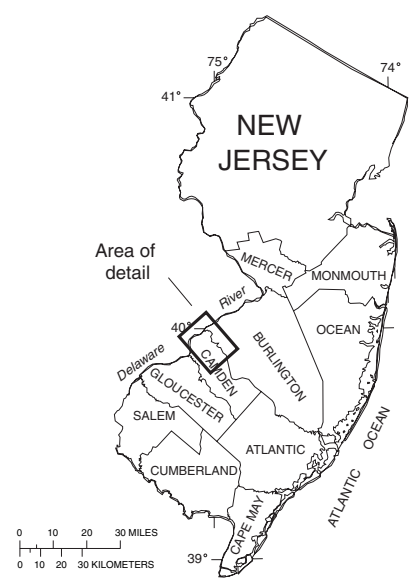

Figure 9. (a) Location of and contributing area for wells Morris 6, 8, and 9; (b) travel-time frequency along flow paths from the Delaware River to the wells; and (c) breakthrough concentration for a single 1-month saltwater-intrusion event. 

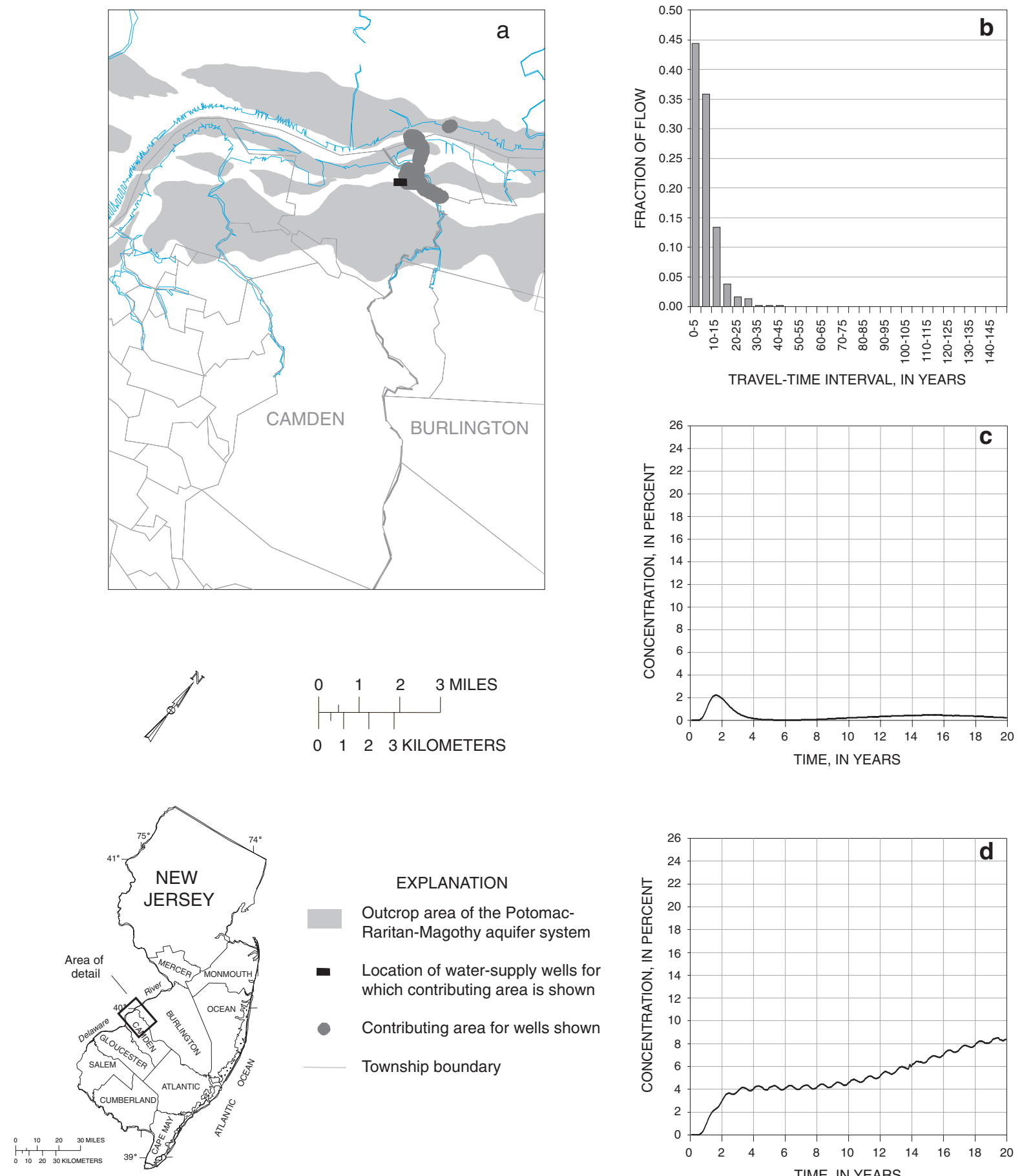

\section{EXPLANATION}

Outcrop area of the PotomacRaritan-Magothy aquifer system

- Location of water-supply wells for which contributing area is shown

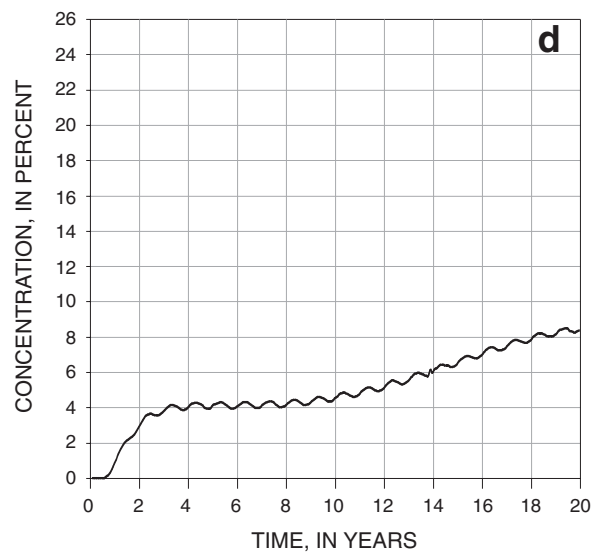

Figure 10. (a) Location of and contributing area for well Morris $3 \mathrm{~A}$; (b) travel-time frequency along flow paths from the Delaware River to the well; and (c) breakthrough concentration for a single 1-month saltwater-intrusion event; and (d) breakthrough concentration for an annually recurring 1-month saltwater-intrusion event. 
The second group of wells listed in table 2 is substantially less vulnerable to saltwater intrusion than the first group. These wells are characterized by flow-path travel times from the river to the well that generally exceed 10 years. Whereas the percentage of river water in the withdrawals from some of these wells is high, the long travel time allows for substantial dilution of the saltwater from the river. Two examples of wells from this group are shown in figures 11 and 12 . The travel times to both wells greatly exceed 10 years (figs. $11 \mathrm{~b}$ and $12 \mathrm{~b}$ ), and the arrival-concentration graphs (figs. $11 \mathrm{c}$ and $12 \mathrm{c}$ ) show virtually no response. Generally, water flowing to these wells from the river has to pass through a confining unit or units, which accounts for the increase in travel time. Although these wells do receive recharge from the river, they have a low vulnerability to intermittent saltwater intrusion. Because virtually no chloride arrived at the wells in this group, no calculation was made (in table 2) to determine the threshold concentrations of dissolved chloride and dissolved sodium in the river for nonpotability conditions to occur in these wells.

The third group of wells listed in table 2 is characterized by withdrawals that contain less than 40 percent river water and by generally small withdrawal rates. Travel times of groundwater flow from the river to wells in this group generally are long because the wells are far from the river. On the basis of the simulation, these wells will not be affected by intermittent saltwater intrusion from the Delaware River.

\section{Limitations of Modeling}

In general, results of ground-water-flow model and particle-tracking analyses are expected to give reasonable approximations of the percentage of ground-water withdrawals that is derived from the river and a good indication of the variations in ground-water travel-time with distance from the river to the well. From these factors alone, wells that are especially vulnerable to saltwater intrusion can be identified.

Although the use of the flow model is appropriate for determining regional ground-water-flow patterns and hydrologic budgets, the model may not represent ground-water flow near wells precisely because of its relatively coarse discretization (the smallest model cells are more than $800 \mathrm{ft}$ on a side). Under pumping conditions, large volumes of ground water travel from a widely distributed source area to a well. Flow converges toward the well and large head gradients develop. Flow models that assign withdrawals to large cells cannot represent adequately these small-scale head gradients that develop near a pumped well. Consequently, estimates of flow-path lengths and ground-water velocities may reflect, in part, coarse model discretization, especially for short flow paths.

The estimate of the fraction of flow from each recharge source, such as the river, was determined from the proportion of total particles and is based on the assumption that an equal flow rate is associated with each particle. This is not strictly true. Flow conditions associated with each particle can differ. To minimize the deviation from this assumption, a large number of particles can be used. Flow-path analysis results for several wells were tested by formulating model runs in which 20, 200, 2,000 , and 20,000 particles were distributed evenly around the walls of the cell containing the well and comparing the resulting contributing areas for each run. The 2,000- and 20,000-particle contributing areas were nearly identical, so 2,000 particles were used in each particle-tracking simulation in backtracking mode.

A one-dimensional analysis of solute transport cannot entirely approximate dispersion in a three-dimensional groundwater-flow system. Transverse dispersivities need to be specified to characterize mechanical dispersion along a path in a three-dimensional flow system more closely. Therefore, the arrival concentrations, or breakthrough curves, produced in this study probably underestimate the full measure of dispersion. This underestimate can be viewed as a "safety factor" in the analysis, because additional dispersion would lower arrival concentrations.

\section{Wells in Salem County}

Because water-supply wells within 2 mi of the Delaware River in Salem County are outside the model area used for Camden and Gloucester Counties, their vulnerability to saltwater intrusion was determined separately. For this analysis, historical chloride-concentration data, water levels, and lithologic logs of wells adjacent to the Delaware River in Salem County were compiled and reviewed. Reports on water quality and the hydrogeology of areas near or including the part of Salem County near the river also were reviewed.

The hydrogeologic framework of the Potomac-RaritanMagothy aquifer system adjacent to the Delaware River in Salem County has not been investigated in detail, but available data are sufficient to determine a generalized (preliminary) hydrogeologic framework. The generalized section shown in figure 13 is based on a previous investigation of the sediments below the Delaware River (Duran, 1986), lithologic logs for wells 33-137 and 33-127, and the geophysical log for well 33302 (Zapecza, 1989, pl. 4). Duran determined that a clay layer at least $50 \mathrm{ft}$ thick underlies the Delaware River in the vicinity of the Delaware Memorial Bridge (fig. 2) and extends upstream about 9 mi. Duran also determined that bedrock is within $10 \mathrm{ft}$ of the Delaware River channel in an area that extends from $2 \mathrm{mi}$ downstream from the Salem-Gloucester County border to about $8 \mathrm{mi}$ above it. The lithologic logs for wells 33-137 and 33-127 indicate a clay layer about $80 \mathrm{ft}$ below land surface. This clay layer may extend under the Delaware River and merge with the clay layer under the Delaware River mapped by Duran. The outcrop area of the confining unit overlying the Middle PotomacRaritan-Magothy aquifer is closer to the Delaware River in Gloucester County (Lewis and others (1991, pl. 6) than in Camden County. This trend continues downstream and into Salem County, but the outcrop area becomes deeper with distance downstream and eventually crops out beneath the Delaware River as shown in figure 13. This clay layer also may be continuous downdip with the clay layer overlying the Middle Potomac-Raritan-Magothy aquifer at well 33-302 shown by Zapecza (1989, pl. 4). 

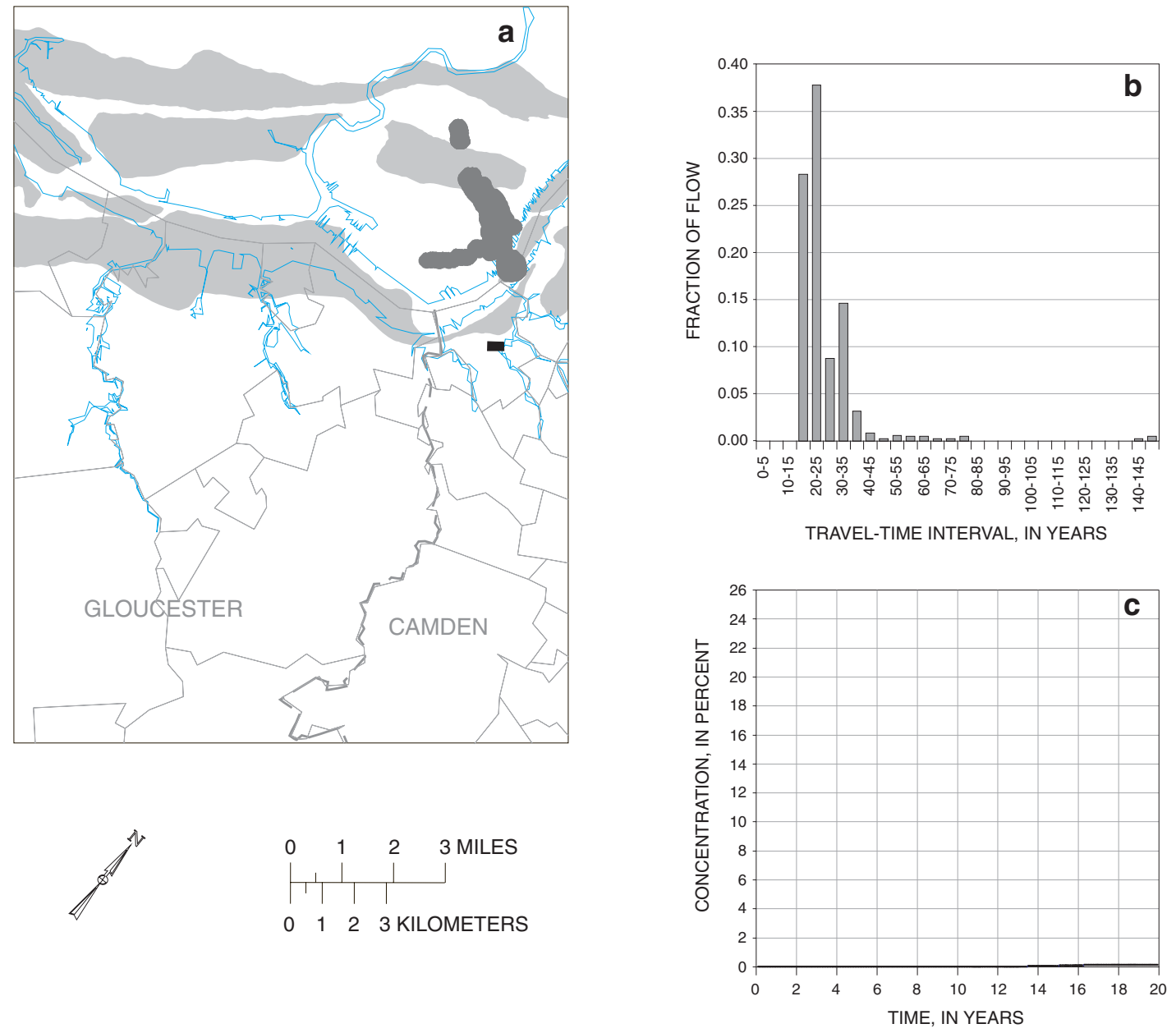

EXPLANATION

Outcrop area of the PotomacRaritan-Magothy aquifer system

- Location of water-supply wells for which contributing area is shown

Contributing area for wells shown

Township boundary

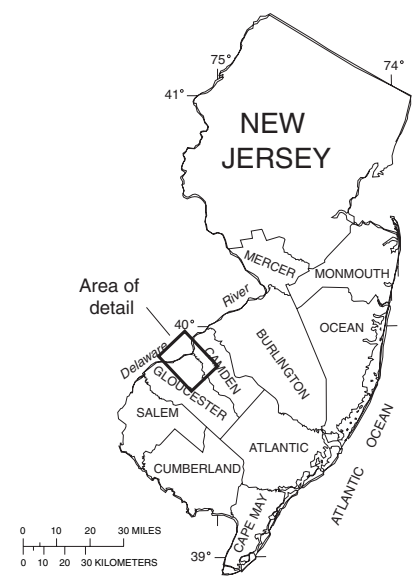

Figure 11. (a) Location of and contributing area for wells GCWD 40, 42, and 43; (b) travel-time frequency along flow paths from the Delaware River to the wells; and (c) breakthrough concentration for a single 1-month saltwater-intrusion event. 

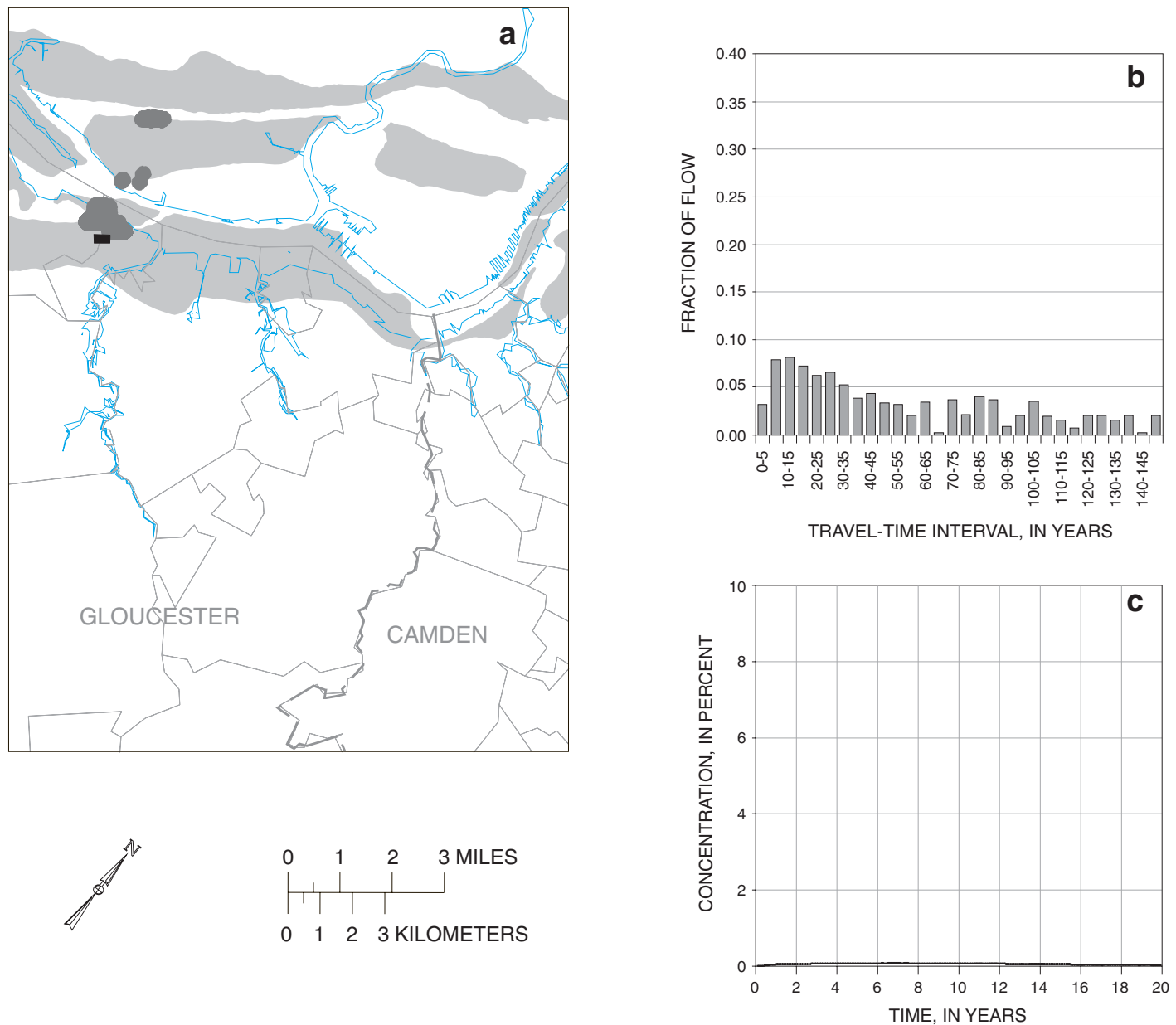

EXPLANATION

Outcrop area of the PotomacRaritan-Magothy aquifer system

- Location of water-supply wells for which contributing area is shown

- Contributing area for wells shown

Township boundary

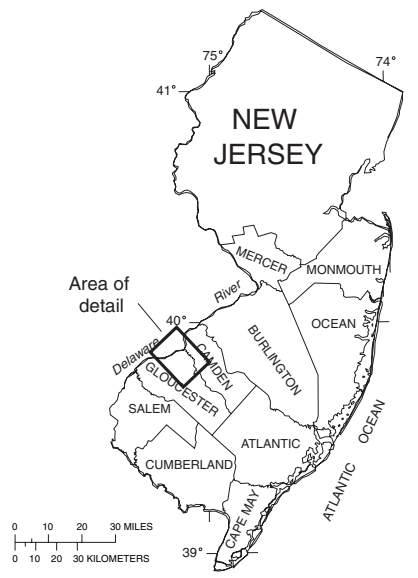

Figure 12. (a) Location of and contributing area for wells RW-5, RW-6, and Mobil 47; (b) travel-time frequency along flow paths from the Delaware River to the wells; and (c) breakthrough concentration for a single 1-month saltwater-intrusion event. 


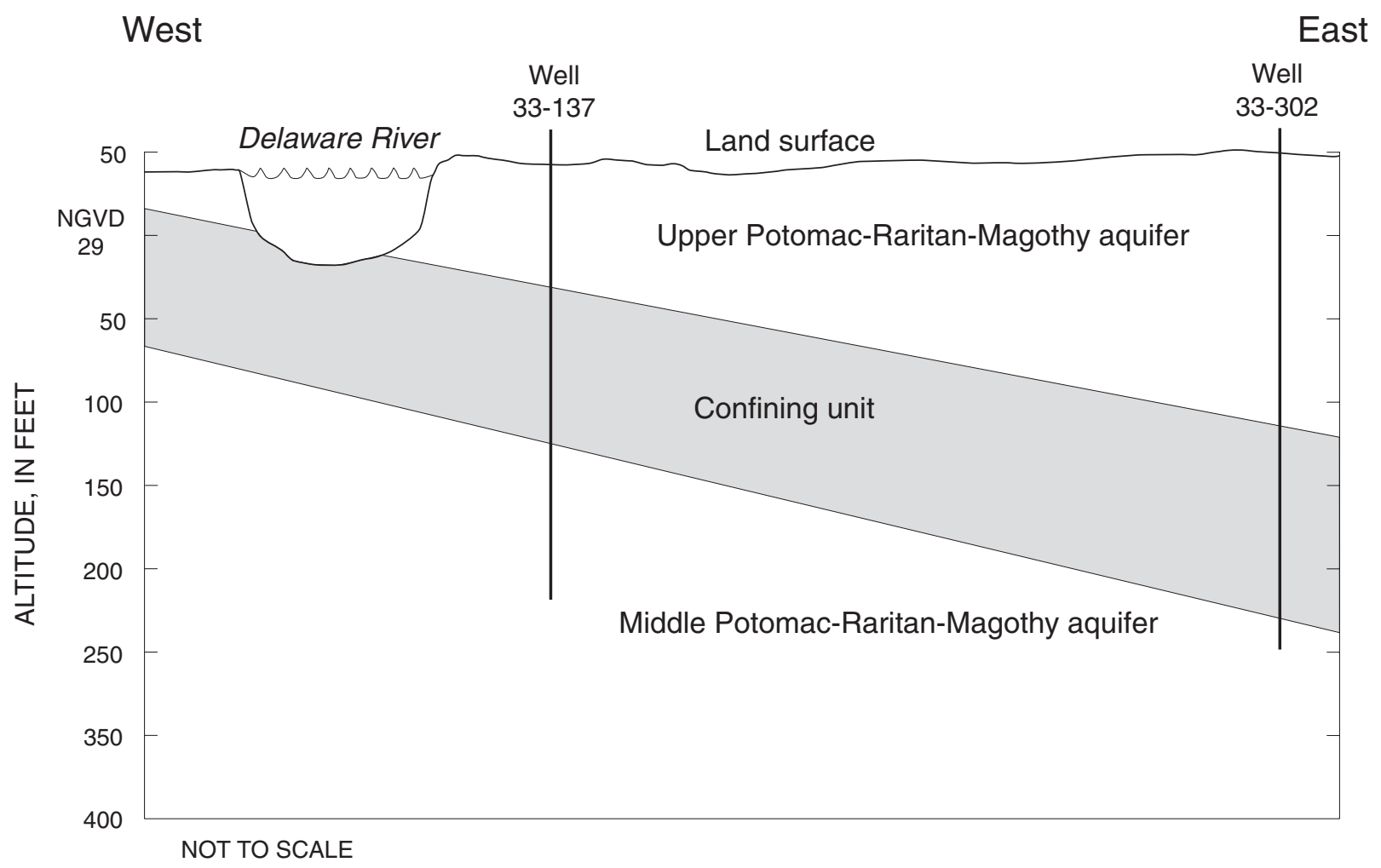

Figure 13. Generalized hydrogeologic section through Salem County, N.J.

The wells in Salem County with the greatest withdrawals are clustered in one area and generally withdraw water from the Middle Potomac-Raritan-Magothy aquifer near the Delaware River. The potentiometric surface of the Middle PotomacRaritan-Magothy aquifer in this area, shown in figure 14, was determined from water levels measured in nine wells in 1988 (Rosman and Lacombe, 1995). The water levels are similar to those measured in 1973 (Walker, 1983) and may indicate that the ground-water-flow system in this area has stabilized with respect to ground-water withdrawals. Fewer water levels were measured in this area during the Coastal Plain-wide synoptic water-level measurement conducted in 1993 (Lacombe and Rosman, 1997) than in previous measurements. The water level in well 33-119 in 1993 was $44 \mathrm{ft}$ below NGVD 1929 ("sea level"); this value is similar to those measured in 1973 (-46 ft) and 1988 (-43 ft). The similarity of these water levels is additional evidence that the ground-water-flow system in this area has stabilized with respect to ground-water withdrawals.
Water levels in wells within 1,000 ft of the Delaware River in Salem County are about 25 to $43 \mathrm{ft}$ lower than those in wells within 1,000 ft of the Delaware River in Camden County. Ground-water withdrawals from wells within $2 \mathrm{mi}$ of the Delaware River in 1996 in Salem County totaled 2,230 Mgal/yr (table 1) and in Camden County totaled 6,529 Mgal/yr. Therefore, water levels in Salem County are lower than those in Camden County, not as a result of greater ground-water withdrawals, but likely because the hydraulic connection of the aquifer system with the Delaware River is more limited in this area than in places upstream from Salem County, such as Pennsauken in Camden County (fig. 2).

Chloride concentrations as high as 2,000 $\mathrm{mg} / \mathrm{L}$ have been measured in the Delaware River at the Salem-Gloucester County line (Hardt and Hilton, 1969). If the hydraulic connection between the Delaware River and the Middle PotomacRaritan-Magothy aquifer was good, chloride concentrations in wells in this area would be high. Although the background 

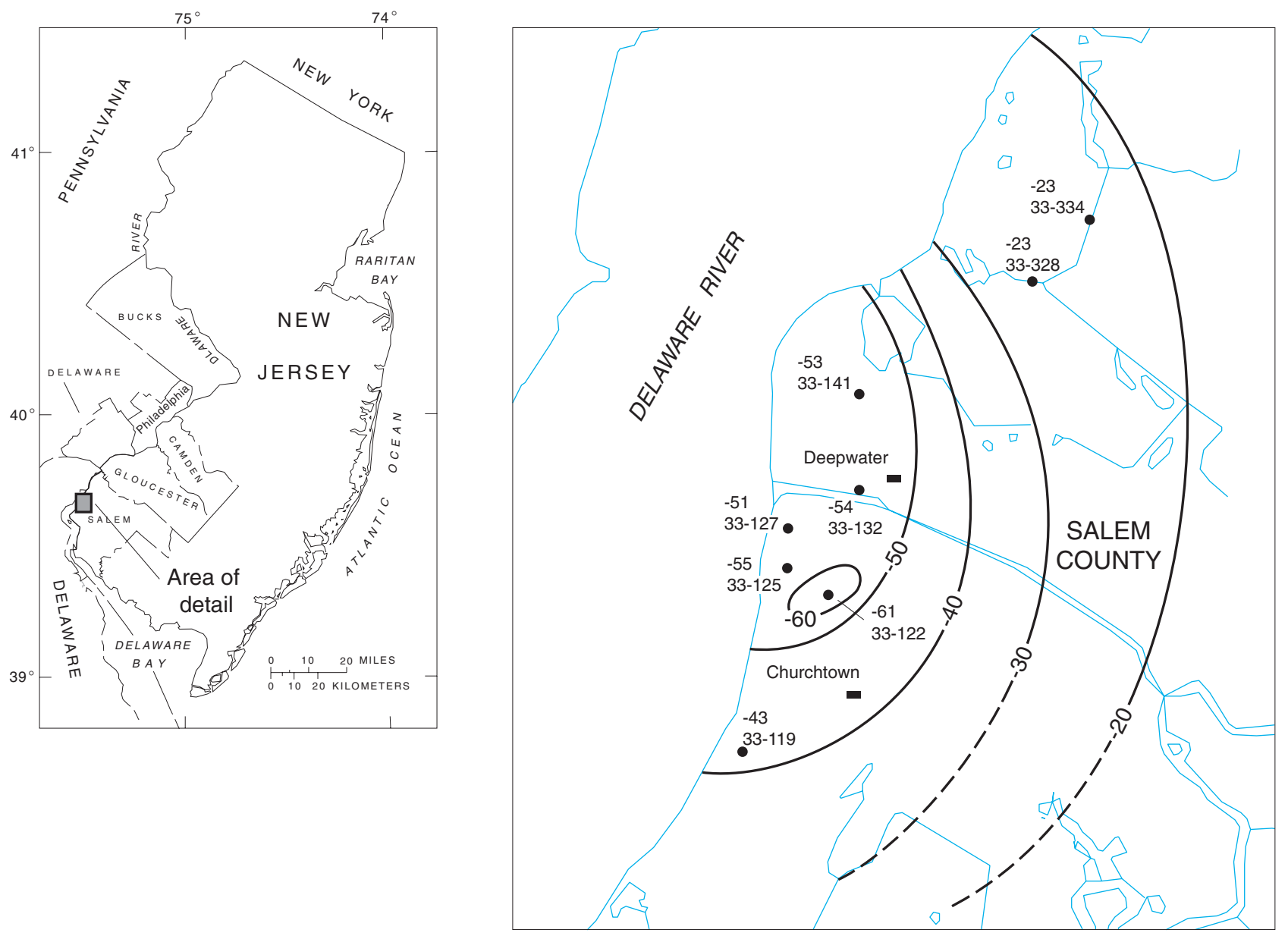

Base from U.S. Geological Survey digital data, 1:100,000, 1983, Universal Transverse

Mercator projection, Zone 18

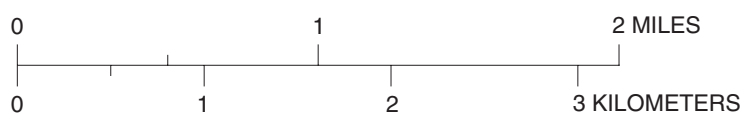

EXPLANATION

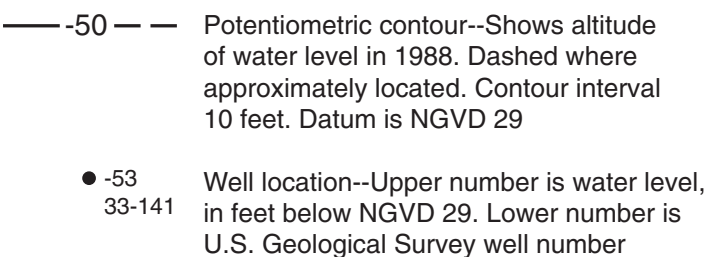

Figure 14. Potentiometric surface of the Middle Potomac-Raritan-Magothy aquifer, Salem County, N.J., 1988. 
values are higher in Salem County than in Camden or Gloucester County, chloride concentrations in water from 12 wells in this area, shown in figure 15 , ranged only from 55 to $317 \mathrm{mg} / \mathrm{L}$.

On the basis of results of previous hydrogeologic investigations, lithologic logs, water levels, and low chloride concentrations in wells within $2 \mathrm{mi}$ of the Delaware River in Salem County, the Middle and Lower Potomac-Raritan-Magothy aquifers appear to be confined in this area and to have only a limited hydraulic connection with the Delaware River.

An estimate of the travel time of ground water from the Delaware River through the confining unit to wells near the Delaware River can be made by means of Darcy's law. Estimated hydraulic conductivities of the confining unit in this area can be calculated from Martin (1998) and range from 0.12775 to $0.2555 \mathrm{ft} / \mathrm{yr}$. If porosity is assumed to be 35 percent and the minimum water level in the Middle Potomac-Raritan-Magothy aquifer is assumed to be $60 \mathrm{ft}$ below sea level, the travel-time calculation indicates that it would take 100 to 225 years for river water to travel from the river, through the confining unit, to water-supply wells in this area. This travel time is substantially longer than that calculated for wells in the part of the study area in Camden and Gloucester Counties. These data suggest that the vulnerability of the Salem County wells to saltwater intrusion from the Delaware River under current pumping conditions is low.

\section{Summary and Conclusions}

The Potomac-Raritan-Magothy aquifer system is hydraulically well connected with the Delaware River in parts of Camden and Gloucester Counties, New Jersey, and has a more limited contact with the river in Salem County, New Jersey. The aquifer system is used widely for water supply, and about 122 production wells (wells with New Jersey Department of Environmental Protection (NJDEP) water-allocation permits) in the three counties are within 2 miles (mi) of the river and withdraw about 12,220 million gallons per year (Mgal/yr). During drought, saltwater may threaten to encroach upstream from the Atlantic Ocean and Delaware Bay to areas that recharge the aquifer system. Additionally, consideration of any sea-levelrise effects amplifies these concerns. During the drought of the mid-1960's, chloride concentrations in the reach of the river that recharges nearby water-supply wells temporarily exceeded the drinking-water (potability) standard of $250 \mathrm{mg} / \mathrm{L}$. Intrusion of this water into the aquifer caused chloride concentrations in some wells to increase temporarily, but these concentrations did not exceed the drinking-water standard.

To address the concern about the potential for saltwater intrusion in the future, a ground-water-flow model, particle tracking, and a one-dimensional ground-water transport model were used to assess the vulnerability of wells in Camden and Gloucester Counties to saltwater intrusion from the Delaware River. Analysis of the ground-water-flow model simulation using particle tracking yielded flow paths, the proportion of flow originating from the river, and velocities for production wells near the river. The path lengths and velocities were used as input to the one-dimensional transport model to determine simulated breakthrough times and concentrations, in terms of percent of initial river concentrations, of induced flow from the Delaware River to the wells. In this manner, the chloride concentration in the Delaware River that would be necessary to render the water in production wells near the river nonpotable was estimated for two scenarios--a single encroachment event lasting 1 month, and intermittent, recurring encroachment events that last 1 month during each year.

A suitable ground-water-flow model for similar use in the Salem County area was not available. Accordingly, an analysis of the hydrogeologic framework and potentiometric surface in the vicinity of production wells in Salem County near the river indicates that the effect of induced infiltration of saltwater from the river on wells can vary greatly depending on the distance of the wells from the river, ground-water withdrawal rates, and the local hydrogeologic framework.

The following conclusions pertaining to the vulnerability of water-supply wells in the Potomac-Raritan-Magothy aquifer system in Camden, Gloucester, and Salem Counties, New Jersey, to saltwater intrusion from the Delaware River can be drawn from the findings of this investigation:

1. There are 122 production wells (wells for which waterallocation permits have been issued by NJDEP) within a 2-mi distance of the Delaware River in Camden, Gloucester, and Salem Counties.

2. The production wells in Camden and Gloucester Counties can be divided into three categories with respect to their vulnerability to saltwater intrusion from the Delaware River during a drought resulting in an intermittent saltwater intrusion event lasting about 1 month (similar to that experienced in the drought of the mid-1960's). The categories are "high," "low," and "no vulnerability."

3. Wells in the high-vulnerability group are those in the Morris and Delair well fields in Camden County (14 percent of the 83 wells investigated in Camden and Gloucester Counties). These wells receive a large percentage of their recharge (50 percent or more) from the Delaware River, have large withdrawals, and are sufficiently close to the river that the travel time from the river to the wells generally is less than 20 years and for several wells is less than 5 years. Because dilution occurs along ground-water-flow paths, however, concentrations of dissolved chloride or dissolved sodium in the river would have to exceed 2,098 $\mathrm{mg} / \mathrm{L}$ or $407 \mathrm{mg} / \mathrm{L}$, respectively, for a single 1-month encroachment event, or $1,818 \mathrm{mg} / \mathrm{L}$ or $358 \mathrm{mg} / \mathrm{L}$, respectively, for an annually recurring 1-month encroachment event to threaten the potability of the water in these wells (if drinking-water standards are assumed to be $250 \mathrm{mg} / \mathrm{L}$ for dissolved chloride and $50 \mathrm{mg} / \mathrm{L}$ for dissolved sodium). The single one-month encroachment event chloride concentration exceeds that measured in the river during the 1960's drought by more than six times. 

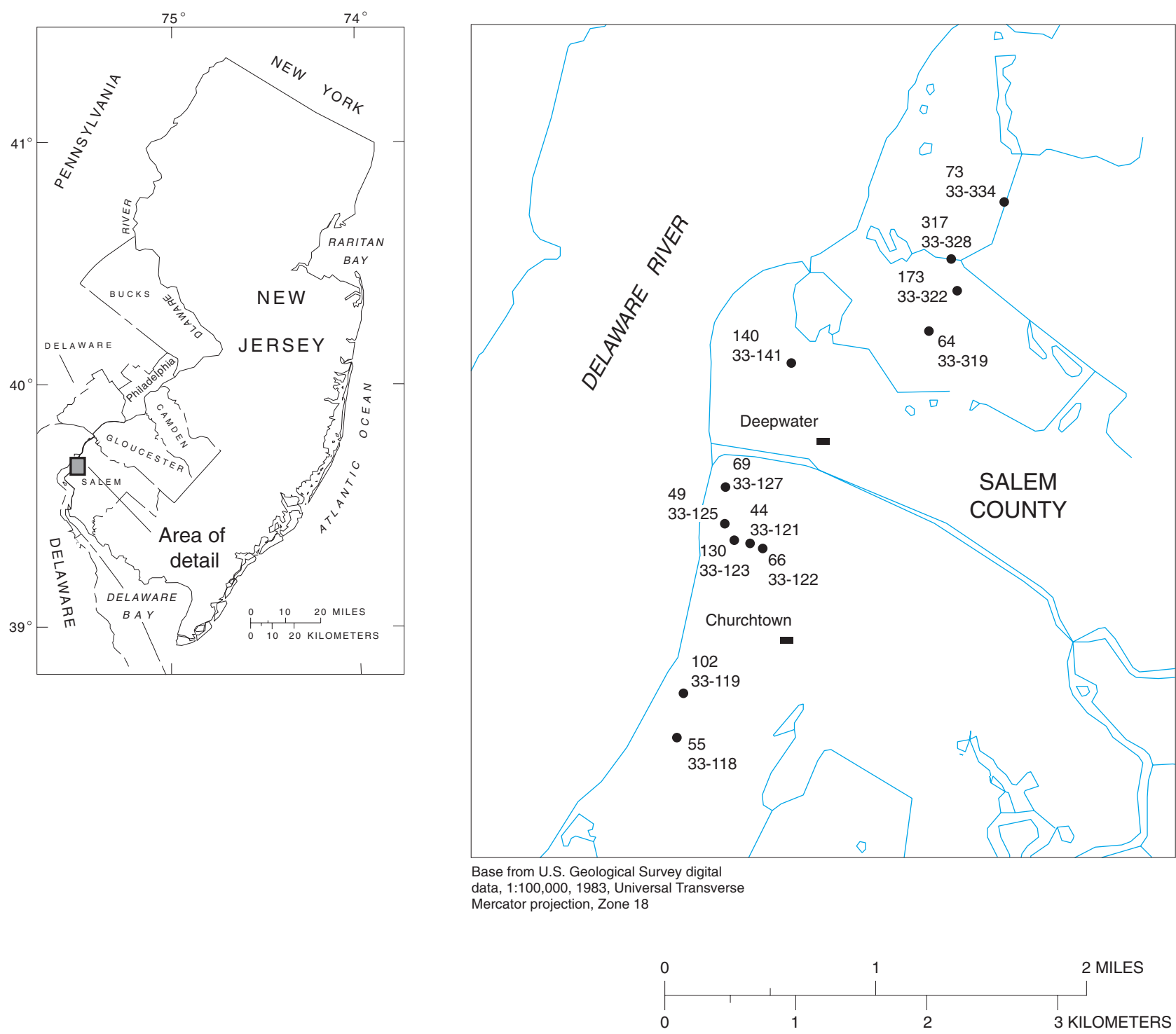

EXPLANATION

140 Well location--Upper number is chloride

33-141 concentration, in milligrams per liter.

Lower number is U.S. Geological Survey well number

Figure 15. Concentration of dissolved chloride from water samples from the Middle Potomac-Raritan-Magothy aquifer, Salem County, N.J., 1968-95. 
4. Wells in the low-vulnerability category include 28 of the 83 wells investigated in Camden and Gloucester

Counties. These wells receive a large percentage of their recharge (40 percent or more) from the river, but the effects of intermittent intrusion of saltwater from the river are minimized because the travel time from river to well is longer than that for the high-vulnerability wells as a result of smaller withdrawal rates or greater distance from the river. The longer travel time, in turn, allows additional dilution to occur. Therefore, concentrations of dissolved chloride or dissolved sodium in the river would have to be substantially higher than the level that would affect the wells in the high-vulnerability category $(1,818 \mathrm{mg} / \mathrm{L}$ or $358 \mathrm{mg} / \mathrm{L}$, respectively) to cause water in these wells to become nonpotable. Consequently, these wells are not considered to be vulnerable to droughtrelated saltwater intrusion.

5. Wells that have a long travel time from river to well (greater than 20 years) and receive only a small amount of their recharge (less than 40 percent) from the river are in the no-vulnerability category. This includes 43 of the 83 wells investigated in Camden and Gloucester Counties. Based on the simulations, these wells do not receive enough recharge from the river to be vulnerable to saltwater intrusion from the river.

6. Analyses of the hydrogeology and potentiometric surface of the Salem County part of the study area indicate that water from the Delaware River flows to the wells through a confining unit. This pathway results in long travel times similar to those associated with wells in the lowvulnerability category in Camden and Gloucester Counties. Although these wells receive recharge from the river, the long travel time substantially reduces the peak constituent concentrations as a result of dilution and dispersion. Because the Salem County wells are farther downstream than those in Camden and Gloucester Counties, chloride concentrations in the adjacent river reach tend to be higher than those in the upstream wells under any given circumstance; therefore, their "baseline" vulnerability is higher. A detailed flow model of the part of Salem County near the river would be needed to assess accurately the vulnerability of these wells to saltwater intrusion.

7. Based on the simulations, if the saltwater-encroachment conditions experienced in the drought of the mid-1960's were to recur, it is unlikely that the potability of water from production wells within $2 \mathrm{mi}$ of the Delaware River that are completed into the Potomac-Raritan-Magothy aquifer system in the Camden/Gloucester/Salem County area would be threatened by the intrusion of saltwater from the river.

\section{References Cited}

Anderson, M.P., 1979, Using models to simulate the movement of contaminants through ground water flow systems: CRC Critical Reviews in Environmental Control, November 1979, p. 97-156.

Bear, Jacob, 1979, Hydraulics of groundwater: New York, McGraw-Hill Book Co., 569 p.

Camp Dresser and McKee, Inc., 1984a, Population and water demand projections: Camden metro study, Task 3 report, submitted to New Jersey Department of Environmental Protection, Division of Water Supply and Watershed Management: Boston, Mass., Camp Dresser and McKee, Inc., 53 p.

Camp Dresser and McKee, Inc., 1984b, Water supply source location and analysis: Camden metro study, Task 4 report, submitted to New Jersey Department of Environmental Protection, Division of Water Supply and Watershed Management: Boston, Mass., Camp Dresser and McKee, Inc., 52 p.

Camp Dresser and McKee, Inc., 1987, Environmental analysis: Camden metro study, Task 8 report, submitted to New Jersey Department of Environmental Protection, Division of Water Supply and Watershed Management: Boston, Mass., Camp Dresser and McKee, Inc., 59 p.

Carslaw, H.S., and Jaeger, J.C., 1959, Conduction of heat in solids (2d ed.): London, Oxford University Press, 510 p.

Duran, P.B., 1986, Distribution of bottom sediments and effects of proposed dredging in the ship channel of the Delaware River between Northeast Philadelphia, Pennsylvania, and Wilmington, Delaware, 1984: U.S. Geological Survey Hydrologic Atlas 697, 1 sheet, scale 1:48,000.

Eckel, J.A., and Walker, R.L., 1986, Water levels in major artesian aquifers of the New Jersey Coastal Plain, 1983: U.S. Geological Survey Water-Resources Investigations Report 86-4028, $62 \mathrm{p}$.

Freeze, R.A., and Cherry, J.A., 1979, Groundwater: Englewood Cliffs, New Jersey, Prentice-Hall, Inc., 604 p.

Gill, H.E., and Farlekas, G.M., 1976, Geohydrologic maps of the Potomac-Raritan-Magothy aquifer system in the New Jersey Coastal Plain: U.S. Geological Survey Atlas HA-557, 2 sheets, scale 1:500,000.

Gillham, R.W., and Cherry, J.A., 1982, Contaminant migration in saturated unconsolidated geologic deposits, in Geological Society of America, Special Paper 189, p. 31-62.

Hardt, W. F., and Hilton, G. S., 1969, Water resources and geology of Gloucester County, New Jersey: Trenton, N.J., New Jersey Department of Conservation and Economic Development Special Report 30, 130 p.

Hoffman, J.L., and Lieberman, S.E., 2000, New Jersey water withdrawals 1990-1996: New Jersey Geological Survey Report, OFR 00-1, 120 p.

Javandel, I., Doughty, C., and Tsang, C.F., 1984, Groundwater transport: Handbook of mathematical models: Water Resources Monograph Series 10, American Geophysical Union, Washington, D.C., 228 p. 
Kolva, J.R., White, T.E., Druther, R.L., and Moleski, P., 1989, Water resources data for Pennsylvania, water year 1987, Volume 1. Delaware River Basin: U.S. Geological Survey Water Data Report PA-87-1, 290 p.

Lacombe, P.J., and Rosman, Robert, 1997, Water levels in, extent of freshwater in, and water withdrawals from eight major confined aquifers, New Jersey Coastal Plain, 1993: U.S. Geological Survey Water-Resources Investigations Report 96-4206, 8 sheets.

Lennon, G.P., Wisniewski, G.M., and Yoshioka, G.A., 1986, Impact of increased river salinity on New Jersey aquifers, in Hull, C.H.J., and Titus, J.G., eds., Greenhouse effect, sea level rise, and salinity in the Delaware Estuary: EPA 230/686-001, Washington, D.C., U.S. Environmental Protection Agency, p. 40-54.

Lewis, J. C., Hochreiter, J. J., Jr., Barton, G.J., Kozinski, Jane, and Spitz, F.J., 1991, Hydrogeology of, and ground-water quality in, the Potomac-Raritan-Magothy aquifer system in the Logan Township region, Gloucester and Salem Counties, New Jersey: U.S. Geological Survey Water-Resources Investigations Report 90-4142, 92 p.

Martin, M.M., 1998, Ground-water flow in the New Jersey Coastal Plain: U.S. Geological Survey Professional Paper 1404-H, 146 p.

McDonald, M.G., and Harbaugh, A.W., 1988, A modular threedimensional finite-difference ground-water flow model: U.S. Geological Survey Techniques of Water-Resources Investigations, chap. A1, book 6, 528 p.

Navoy, A.S., 1991, Aquifer-estuary interaction and vulnerability of ground-water supplies to sea-level-rise driven saltwater intrusion: University Park, Pennsylvania, The Pennsylvania State University, unpublished Ph.D. dissertation, 225 p.

Navoy, A.S., and Carleton, G.B., 1995, Ground-water flow and future conditions in the Potomac-Raritan-Magothy aquifer system, Camden area, New Jersey: New Jersey Geological Survey Report, GSR 38, 184 p.
New Jersey Administrative Code, 1989, Safe Drinking Water Act: N.J.A.C. 7:10 - 1 through 16.12.

New Jersey Administrative Code, 1995, Water supply allocation rules: N.J.A.C. 7:1.1 - et seq., February 1995, 81 p.

New Jersey Department of Environmental Protection, 1986, Procedures for implementation of Water Supply Critical Area No. 2: Trenton, New Jersey, New Jersey Department of Environmental Protection, Division of Water Resources, December 1986, 9 p.

Pollock, D.W., 1988, Semianalytical computation of path lines for finite-difference models: Ground Water, v. 26, no. 6, p. 743-750.

Pollock, D.W., 1989, Documentation of computer programs to compute and display pathlines using results from the U.S. Geological Survey modular three-dimensional finite-difference ground-water flow model: U.S. Geological Survey Open-File Report 89-381, 188 p.

Rosman, Robert, and Lacombe, P.J., 1995, Water levels in major artesian aquifers of the New Jersey Coastal Plain, 1988: U.S. Geological Survey Water-Resources Investigations Report 95-4060, 10 pl.

U.S. Geological Survey, 1965, Water resources data for Pennsylvania, 1965, part 2. Water quality records: Philadelphia, Pa., U.S. Geological Survey, 211 p.

U.S. Geological Survey, 1967, Engineering geology of the Northeast Corridor, Washington, D.C., to Boston, Massachusetts: Coastal Plain and surficial deposits: U.S. Geological Survey Miscellaneous Investigations Map 514-B, 8 sheets, scale 1:250,000.

Walker, R.L., 1983, Evaluation of water levels in major aquifers of the New Jersey Coastal Plain, 1978: U.S. Geological Survey Water-Resources Investigations Report 82-4077, $56 \mathrm{p}$.

Zapecza, O.S., 1989, Hydrogeologic framework of the New Jersey Coastal Plain: U.S. Geological Survey Professional Paper 1404-B, 49 p., 24 pl. 
Table 1. Locations of, construction data for, and withdrawals from wells capable of withdrawing more than 100,000 gallons per day that are within 2 miles of the Delaware River in Camden, Gloucester, and Salem Counties, N.J.

[NJDEP, New Jersey Department of Environmental Protection; Mgal/yr, million gallons per year; --, no data; Aquifer codes: QRNR, Quaternary deposits; HPPN, undifferentiated Holocene, Pleistocene, Pliocene, and (or) Miocene deposits; MLRW, Wenonah-Mt. Laurel aquifer; MRPA, Potomac-Raritan-Magothy undifferentiated; MRPAU, Upper Potomac-Raritan-Magothy aquifer; MRPAM, Middle PotomacRaritan-Magothy aquifer; MRPAL, Lower Potomac-Raritan-Magothy aquifer]

\begin{tabular}{|c|c|c|c|c|c|c|c|c|c|}
\hline \multirow{2}{*}{$\begin{array}{c}\text { Map } \\
\text { number } \\
\text { of well in } \\
\text { figure } 1\end{array}$} & \multirow[t]{2}{*}{ Well owner } & \multirow[t]{2}{*}{ Local well name } & \multirow{2}{*}{$\begin{array}{c}\text { Well } \\
\text { number }\end{array}$} & \multirow{2}{*}{$\begin{array}{l}\text { Aquifer } \\
\text { code }\end{array}$} & \multirow{2}{*}{$\begin{array}{c}\text { Altitude of } \\
\text { land surface } \\
\text { (feet above } \\
\text { NGVD 1929) }\end{array}$} & \multicolumn{2}{|c|}{$\begin{array}{c}\text { Open interval } \\
\text { (feet below land } \\
\text { surface) }\end{array}$} & \multirow{2}{*}{$\begin{array}{l}\text { NJDEP } \\
\text { permit } \\
\text { number }\end{array}$} & \multirow{2}{*}{$\begin{array}{c}1996 \\
\text { withdrawals } \\
\text { (Mgal/yr) }\end{array}$} \\
\hline & & & & & & Top & Bottom & & \\
\hline \multicolumn{10}{|c|}{ Camden County } \\
\hline 1 & BELLMAWR B W D & BBWD 3 & $7-12$ & MRPAL & 35 & 334 & 359 & $31-02687$ & 28.919 \\
\hline 2 & BELLMAWR B W D & BBWD 6 & $7-601$ & MRPAL & 40 & 330 & 381 & $31-19218$ & 45.456 \\
\hline 3 & BROOKLAWN B W D & BBWD 3 & $7-520$ & MRPAL & 10 & 307 & 327 & $31-04325$ & 23.367 \\
\hline 4 & BROOKLAWN B W D & BBWD 5(OW 3) & $7-531$ & MRPAL & 10 & 300 & 320 & $31-14471$ & 25.492 \\
\hline 5 & BROOKLAWN B W D & BBWD 4 & $7-596$ & MRPAL & 10 & 263 & 293 & $31-19765$ & 58.2 \\
\hline 6 & CAMDEN CITY W D & CITY 11 & $7-46$ & MRPAM & 13 & 124 & 154 & $51-00061$ & 11.81 \\
\hline 7 & CAMDEN CITY W D & DELAIR 1 & $7-368$ & MRPAL & 10 & 106 & 126 & $51-00053$ & 333.875 \\
\hline 8 & CAMDEN CITY W D & DELAIR 2 & $7-369$ & MRPAL & 5 & 111 & 141 & $51-00054$ & 333.875 \\
\hline 9 & CAMDEN CITY W D & DELAIR 3 & $7-370$ & MRPAL & 6 & 87 & 127 & $51-00055$ & 333.875 \\
\hline 10 & CAMDEN CITY W D & MORRIS 6 & $7-373$ & MRPAL & 5.9 & 98 & 133 & $51-00051$ & 333.875 \\
\hline 11 & CAMDEN CITY W D & MORRIS 9 & $7-374$ & MRPAL & 6.8 & 99 & 118 & $51-00076$ & 333.875 \\
\hline 12 & CAMDEN CITY W D & MORRIS 8 & $7-375$ & MRPAL & 6 & 89 & 124 & $31-00944$ & 333.875 \\
\hline 13 & CAMDEN CITY W D & MORRIS 7 & $7-377$ & MRPAL & 6 & 85 & 120 & $51-00052$ & 333.875 \\
\hline 14 & CAMDEN CITY W D & MORRIS 10 & $7-379$ & MRPAL & 8.7 & 75 & 115 & $31-04251$ & 333.875 \\
\hline 15 & CAMDEN CITY W D & MORRIS 3A & $7-386$ & MRPAL & 10 & 73 & 103 & $31-00945$ & 333.875 \\
\hline 16 & CAMDEN CITY W D & MORRIS 1 & $7-390$ & MRPAL & 6 & 93 & 118 & $51-00050$ & 333.875 \\
\hline 17 & CAMDEN CITY W D & PARKSIDE 18 & $7-527$ & MRPAL & 40 & 258 & 288 & $31-09574$ & 201.84 \\
\hline 18 & CAMDEN CITY W D & MORRIS 11 & $7-545$ & MRPAL & 15.3 & 102 & 144 & $31-15745$ & 333.875 \\
\hline 19 & CAMDEN CITY W D & MORRIS 12 & $7-586$ & MRPAL & 10 & 86 & 117 & $31-16814$ & 333.875 \\
\hline 20 & CAMDEN CITY W D & MORRIS 13 & $7-587$ & MRPAL & 10 & 90 & 130 & $31-16813$ & 333.875 \\
\hline 21 & GLOUCESTER C WD & GCWD 42 & $7-210$ & MRPAL & 15 & -- & -- & $31-05242$ & 17.547 \\
\hline 22 & GLOUCESTER C WD & GCWD 40 & $7-220$ & MRPAL & 10 & 221 & 261 & $31-04306$ & 149.51 \\
\hline
\end{tabular}


Table 1. Locations of, construction data for, and withdrawals from wells capable of withdrawing more than 100,000 gallons per day that are within 2 miles of the Delaware River in Camden, Gloucester, and Salem Counties, N.J.-Continued

[NJDEP, New Jersey Department of Environmental Protection; Mgal/yr, million gallons per year; --, no data; Aquifer codes: QRNR, Quaternary deposits; HPPN, undifferentiated Holocene, Pleistocene,

Pliocene, and (or) Miocene deposits; MLRW, Wenonah-Mt. Laurel aquifer; MRPA, Potomac-Raritan-Magothy undifferentiated; MRPAU, Upper Potomac-Raritan-Magothy aquifer; MRPAM, Middle PotomacRaritan-Magothy aquifer; MRPAL, Lower Potomac-Raritan-Magothy aquifer]

\begin{tabular}{|c|c|c|c|c|c|c|c|c|c|}
\hline \multirow{2}{*}{$\begin{array}{c}\text { Map } \\
\text { number } \\
\text { of well in } \\
\text { figure } 1\end{array}$} & \multirow[t]{2}{*}{ Well owner } & \multirow[t]{2}{*}{ Local well name } & \multirow{2}{*}{$\begin{array}{c}\text { Well } \\
\text { number }\end{array}$} & \multirow{2}{*}{$\begin{array}{l}\text { Aquifer } \\
\text { code }\end{array}$} & \multirow{3}{*}{$\begin{array}{c}\text { Altitude of } \\
\text { land surface } \\
\text { (feet above } \\
\text { NGVD 1929) }\end{array}$} & \multicolumn{2}{|c|}{$\begin{array}{c}\text { Open interval } \\
\text { (feet below land } \\
\text { surface) }\end{array}$} & \multirow{2}{*}{$\begin{array}{l}\text { NJDEP } \\
\text { permit } \\
\text { number }\end{array}$} & \multirow{2}{*}{$\begin{array}{c}1996 \\
\text { withdrawals } \\
\text { (Mgal/yr) }\end{array}$} \\
\hline & & & & & & Top & Bottom & & \\
\hline \multicolumn{9}{|c|}{ Camden County--Continued } & \\
\hline 23 & GLOUCESTER C WD & GCWD 43 & $7-516$ & MRPAL & 10 & 220 & 260 & $31-18822$ & 53.152 \\
\hline 24 & GLOUCESTER C WD & $\begin{array}{l}\text { GCWD 41/AKA } 3104903 \\
\text { RD }\end{array}$ & $7-902$ & MRPAU & 10 & 225 & 265 & $31-27737$ & 207.447 \\
\hline 25 & MACANDREWS \& FORBES CO & M\&F IND 3R & $7-825$ & MRPAM & 10 & 86 & 146 & $31-42789$ & 33.402 \\
\hline 26 & MAFCO & MAFCO 4R/1 & $7-43$ & MRPAM & 12 & 82 & 103 & $31-00290$ & 10.061 \\
\hline 27 & MCHVIL PNSK WCM & $1 \mathrm{R}$ & $7-319$ & MRPAM & 15 & 132 & 152 & $31-05641$ & 277.867 \\
\hline 28 & MCHVIL PNSK WCM & WOODBINE 1 & $7-320$ & MRPAL & 69 & 245 & 285 & $31-04642$ & 47.744 \\
\hline 29 & MCHVIL PNSK WCM & MARION 1 & $7-335$ & MRPAL & 61 & 243 & 278 & $31-02915$ & 139.934 \\
\hline 30 & MCHVIL PNSK WCM & NATIONAL HWY 1 & $7-372$ & MRPAL & 68 & 195 & 230 & $31-05110$ & 0.271 \\
\hline 31 & MCHVIL PNSK WCM & WOODBINE 2 & $7-560$ & MRPAL & 58 & 196 & 226 & $31-14563$ & 66.769 \\
\hline 32 & MCHVIL PNSK WCM & NATIONAL HWY 2 & $7-602$ & MRPAL & 35 & 182 & 206 & $31-19207$ & 306.04 \\
\hline 33 & NEW JERSEY WATER CO & CLEVELAND AVE PW 53 & $7-724$ & MRPAL & 32 & 154 & 194 & $31-18947$ & 120.404 \\
\hline 34 & NJ/AMERICAN WATER CO & CAMDEN DIV 52 & $7-98$ & MRPAL & 18 & 147 & 198 & $31-04847$ & 204.04 \\
\hline 35 & NJ/AMERICAN WATER CO & 54 & $7-547$ & MRPAL & 35 & 155 & 195 & $31-18944$ & 154.655 \\
\hline 36 & NJ/AMERICAN WATER CO & 55 & $7-597$ & MRPAL & 11 & 136 & 176 & $31-20270$ & 5.498 \\
\hline \multirow[t]{2}{*}{37} & OUR LADY HOSP & STAND BY WELL & $7-57$ & MRPAL & 30 & 237 & 258 & $31-04620$ & 0.01 \\
\hline & & & & & & & & Total & $6,529.81$ \\
\hline \multicolumn{10}{|c|}{ Gloucester County } \\
\hline 38 & BP OIL CO & BP R-6-A & $15-1120$ & MRPAM & 14 & 6 & 72 & $30-07032$ & 40.234 \\
\hline 39 & BP OIL CO & BP R-8-A & $15-1121$ & MRPAM & 14 & 39 & 85 & $30-07014$ & 16.489 \\
\hline 40 & BP OIL CO & BP R-9-A & $15-1122$ & MRPAM & 14 & 45 & 90 & $30-07015$ & 17.349 \\
\hline 41 & BP OIL CO & BP R-7-A & $15-1124$ & MRPAM & 32 & 95 & 40 & $30-07012$ & 16.022 \\
\hline 42 & $\begin{array}{l}\text { BP OIL COMPANY - PAULSBORO } \\
\text { TERMINAL }\end{array}$ & BP R-4A & $15-1378$ & HPPM & 20 & 11 & 82 & $30-06920$ & 19.921 \\
\hline 43 & $\begin{array}{l}\text { BP OIL COMPANY - PAULSBORO } \\
\text { TERMINAL }\end{array}$ & BP R-10A & $15-1383$ & HPPM & 15 & 9 & 39 & $30-07028$ & 7.204 \\
\hline
\end{tabular}


Table 1. Locations of, construction data for, and withdrawals from wells capable of withdrawing more than 100,000 gallons per day that are within 2 miles of the Delaware River in Camden, Gloucester, and Salem Counties, N.J.-Continued

[NJDEP, New Jersey Department of Environmental Protection; Mgal/yr, million gallons per year; --, no data; Aquifer codes: QRNR, Quaternary deposits; HPPN, undifferentiated Holocene, Pleistocene,

Pliocene, and (or) Miocene deposits; MLRW, Wenonah-Mt. Laurel aquifer; MRPA, Potomac-Raritan-Magothy undifferentiated; MRPAU, Upper Potomac-Raritan-Magothy aquifer; MRPAM, Middle PotomacRaritan-Magothy aquifer; MRPAL, Lower Potomac-Raritan-Magothy aquifer]

\begin{tabular}{|c|c|c|c|c|c|c|c|c|c|}
\hline \multirow{2}{*}{$\begin{array}{c}\text { Map } \\
\text { number } \\
\text { of well in } \\
\text { figure } 1\end{array}$} & \multirow[t]{2}{*}{ Well owner } & \multirow[t]{2}{*}{ Local well name } & \multirow{2}{*}{$\begin{array}{c}\text { Well } \\
\text { number }\end{array}$} & \multirow{2}{*}{$\begin{array}{l}\text { Aquifer } \\
\text { code }\end{array}$} & \multirow{2}{*}{$\begin{array}{c}\text { Altitude of } \\
\text { land surface } \\
\text { (feet above } \\
\text { NGVD 1929) }\end{array}$} & \multicolumn{2}{|c|}{$\begin{array}{c}\text { Open interval } \\
\text { (feet below land } \\
\text { surface) }\end{array}$} & \multirow{2}{*}{$\begin{array}{l}\text { NJDEP } \\
\text { permit } \\
\text { number }\end{array}$} & \multirow{2}{*}{$\begin{array}{c}1996 \\
\text { withdrawals } \\
\text { (Mgal/yr) }\end{array}$} \\
\hline & & & & & & Top & Bottom & & \\
\hline \multicolumn{10}{|c|}{ Gloucester County--Continued } \\
\hline 44 & $\begin{array}{l}\text { BP OIL COMPANY - SOHIO } \\
\text { PAULSBORO }\end{array}$ & BP 51-1 & $15-1381$ & HPPM & 13.89 & 8 & 28 & $30-05153$ & .178 \\
\hline 45 & $\begin{array}{l}\text { BP OIL COMPANY - SOHIO } \\
\text { PAULSBORO }\end{array}$ & BP RECOVERY 2 & $15-1382$ & HPPM & 15 & 4 & 24 & $30-05183$ & 7.004 \\
\hline 46 & $\begin{array}{l}\text { COASTAL EAGLE POINT OIL } \\
\text { COMPANY }\end{array}$ & EAGLE POINT 7 & $15-317$ & MRPAL & 10 & 261 & 301 & $31-06834$ & 140.319 \\
\hline 47 & $\begin{array}{l}\text { COASTAL EAGLE POINT OIL } \\
\text { COMPANY }\end{array}$ & EAGLE POINT 1 & $15-320$ & MRPAL & 20 & 248 & 288 & $31-00007$ & 85.453 \\
\hline 48 & $\begin{array}{l}\text { COASTAL EAGLE POINT OIL } \\
\text { COMPANY }\end{array}$ & EAGLE POINT 3 & $15-322$ & MRPAL & 20 & 258 & 288 & $31-00008$ & 73.697 \\
\hline 49 & $\begin{array}{l}\text { COASTAL EAGLE POINT OIL } \\
\text { COMPANY }\end{array}$ & EAGLE POINT 6A & $15-430$ & MRPAL & 15 & 256 & 328 & $31-17788$ & 222.526 \\
\hline 50 & E I DUPONT & REPAUNO 3 & $15-72$ & MRPAM & 6 & 91 & 101 & $30-00037$ & 151.512 \\
\hline 51 & E I DUPONT & REPAUNO 6 & $15-79$ & MRPAM & 10 & 84 & 109 & $30-01145$ & 25.648 \\
\hline 52 & E I DUPONT & INTERCEPTOR 46 & $15-692$ & MRPAM & 5 & 96 & 136 & $30-03594$ & 162.461 \\
\hline 53 & GREENWICH T W D & GTWD 5 (2-A) & $15-347$ & MRPAM & 20 & 82 & 117 & $30-01545$ & 137.675 \\
\hline 54 & GREENWICH T W D & GTWD 6 & $15-348$ & MRPAM & 20 & 105 & 135 & $30-01776$ & 103.554 \\
\hline 55 & GREENWICH T W D & MEMORIAL AVE 4R & $15-1364$ & MRPAM & 15 & 98 & 166 & $30-09345$ & 107.177 \\
\hline 56 & HERCULES CHEMICAL & 41970 & $15-76$ & MRPAM & 15 & 905 & 120.5 & $30-01224$ & 25.389 \\
\hline 57 & HERCULES INC & HERCULES PW 11 & $15-1034$ & MRPAM & 10 & 90 & 120 & 30-04319 & 51.364 \\
\hline 58 & HERCULES INC - HIGGINS PLANT & HERCULES PW-10 & $15-1373$ & MRPAM & 12 & 14.7 & 45 & $30-04426$ & 9.773 \\
\hline 59 & LOGAN WELLS WATER CO & LWWC BIRCH CK RD 4 & $15-1362$ & MRPAM & 19 & 56 & 91 & 30-09444 & 85.095 \\
\hline 60 & MOBIL OIL COMPANY & MOBIL 47 & $15-118$ & MRPAL & 18 & 220 & 240 & 30-00198 & 3.405 \\
\hline 61 & MOBIL OIL COMPANY & RW-5 & $15-823$ & QRNR & 25.4 & 18 & 53 & 30-01909 & 22.869 \\
\hline 62 & MOBIL OIL COMPANY & RW-6 & $15-824$ & QRNR & 18.8 & 135 & 48.5 & 30-01905 & 50.047 \\
\hline 63 & MOBIL OIL COMPANY & RW-8 & $15-826$ & QRNR & 19 & 15 & 50 & 30-01906 & 5.973 \\
\hline
\end{tabular}


Table 1. Locations of, construction data for, and withdrawals from wells capable of withdrawing more than 100,000 gallons per day that are within 2 miles of the Delaware River in Camden, Gloucester, and Salem Counties, N.J.-Continued

[NJDEP, New Jersey Department of Environmental Protection; Mgal/yr, million gallons per year; --, no data; Aquifer codes: QRNR, Quaternary deposits; HPPN, undifferentiated Holocene, Pleistocene,

Pliocene, and (or) Miocene deposits; MLRW, Wenonah-Mt. Laurel aquifer; MRPA, Potomac-Raritan-Magothy undifferentiated; MRPAU, Upper Potomac-Raritan-Magothy aquifer; MRPAM, Middle PotomacRaritan-Magothy aquifer; MRPAL, Lower Potomac-Raritan-Magothy aquifer]

\begin{tabular}{|c|c|c|c|c|c|c|c|c|c|}
\hline \multirow{2}{*}{$\begin{array}{c}\text { Map } \\
\text { number } \\
\text { of well in } \\
\text { figure } 1\end{array}$} & \multirow[t]{2}{*}{ Well owner } & \multirow[t]{2}{*}{ Local well name } & \multirow{2}{*}{$\begin{array}{c}\text { Well } \\
\text { number }\end{array}$} & \multirow{2}{*}{$\begin{array}{l}\text { Aquifer } \\
\text { code }\end{array}$} & \multirow{2}{*}{$\begin{array}{l}\text { Altitude of } \\
\text { land surface } \\
\text { (feet above } \\
\text { NGVD 1929) }\end{array}$} & \multicolumn{2}{|c|}{$\begin{array}{c}\text { Open interval } \\
\text { (feet below land } \\
\text { surface) }\end{array}$} & \multirow{2}{*}{$\begin{array}{l}\text { NJDEP } \\
\text { permit } \\
\text { number }\end{array}$} & \multirow{2}{*}{$\begin{array}{c}1996 \\
\text { withdrawals } \\
\text { (Mgal/yr) }\end{array}$} \\
\hline & & & & & & Top & Bottom & & \\
\hline \multicolumn{10}{|c|}{ Gloucester County--Continued } \\
\hline 64 & MOBIL OIL COMPANY & MOBIL 48 DWTA & $15-1039$ & MRPAM & 7 & 100 & 153 & $30-05060$ & 90.081 \\
\hline 65 & MOBIL OIL COMPANY & MOBIL RW-19 & $15-1374$ & MRPAM & 5 & 15 & 55.7 & $30-05642$ & 140.96 \\
\hline 66 & MONSANTO CHEM & BRIDGEPORT W2 & $15-158$ & MRPAM & 12 & 57 & 82 & $30-00873$ & 200.006 \\
\hline 67 & MONSANTO CHEM & BRIDGEPORT E1 & $15-159$ & MRPAM & 11 & 56 & 81 & $30-00872$ & 59.579 \\
\hline 68 & MONSANTO CHEM & MONSANTO 1 & $15-167$ & MRPAM & 10 & 64 & 94 & $30-01170$ & 107.841 \\
\hline 69 & NATIONAL PK W D & NPWD 2/NPWD 5 & $15-207$ & MRPAL & 30 & 241 & 282 & $31-02555$ & 48.195 \\
\hline 70 & NATIONAL PK W D & NPWD 6 & $15-533$ & MRPAL & 22 & 240 & 272 & $31-17938$ & 66.433 \\
\hline 71 & PAULSBORO W D & $1973-6$ & $15-210$ & MRPAM & 15 & 185 & 227 & $30-01348$ & 111.811 \\
\hline 72 & PAULSBORO W D & PWD 4 & $15-212$ & MRPAM & 25 & 192 & 220 & 30-00069 & 53.828 \\
\hline 73 & PAULSBORO W D & PWD 5 & $15-213$ & MRPAM & 10 & 135 & 175 & $30-00602$ & 114.423 \\
\hline 74 & PENNS GROVE WSC & BRIDGEPORT BACKUP-2 & $15-697$ & MRPAM & 8 & 69 & 84 & $30-03332$ & 4.899 \\
\hline 75 & PENNS GROVE WSC & BRIDGEPORT 2 & $15-166$ & MRPAM & 5 & 654 & 85.4 & $30-00410$ & 31.818 \\
\hline 76 & PENNWALT CORP & 418 & $15-304$ & MRPAL & 10 & 237 & 289 & $30-01173$ & 7.29 \\
\hline 77 & PENNWALT CORP & 417 & $15-306$ & MRPAL & 10 & 234 & 276 & $30-01174$ & 288.57 \\
\hline 78 & TEXAS OIL CO & EAGLE POINT 4A & $15-410$ & MRPAL & 5 & 256 & 296 & $31-10647$ & 1.908 \\
\hline 79 & W DEPTFORD T WD & 6 RED BANK AVE & $15-312$ & MRPAL & 20 & 322 & 372 & $51-00063$ & 135.476 \\
\hline 80 & W DEPTFORD T WD & WDTWD 7 & $15-373$ & MRPAL & 28 & 323 & 363 & $31-17452$ & 216.473 \\
\hline 81 & WESTVILLE W D & WWD 5 & $15-326$ & MRPAL & 12 & 243 & 277 & $31-05689$ & 141.34 \\
\hline 82 & WESTVILLE W D & WWD 4 & $15-327$ & MRPAL & 16 & 286 & 313 & $31-03418$ & 45.884 \\
\hline 83 & WESTVILLE W D & WWD 6 & $15-434$ & MRPAL & 15 & 265 & 317 & $31-17923$ & 5.277 \\
\hline & & & & & & & & Total & $3,460.43$ \\
\hline
\end{tabular}


Table 1. Locations of, construction data for, and withdrawals from wells capable of withdrawing more than 100,000 gallons per day that are within 2 miles of the Delaware River in Camden, Gloucester, and Salem Counties, N.J.-Continued

[NJDEP, New Jersey Department of Environmental Protection; Mgal/yr, million gallons per year; --, no data; Aquifer codes: QRNR, Quaternary deposits; HPPN, undifferentiated Holocene, Pleistocene,

Pliocene, and (or) Miocene deposits; MLRW, Wenonah-Mt. Laurel aquifer; MRPA, Potomac-Raritan-Magothy undifferentiated; MRPAU, Upper Potomac-Raritan-Magothy aquifer; MRPAM, Middle PotomacRaritan-Magothy aquifer; MRPAL, Lower Potomac-Raritan-Magothy aquifer]

\begin{tabular}{|c|c|c|c|c|c|c|c|c|c|}
\hline \multirow{2}{*}{$\begin{array}{c}\text { Map } \\
\text { number } \\
\text { of well in } \\
\text { figure } 1\end{array}$} & \multirow[t]{2}{*}{ Well owner } & \multirow[t]{2}{*}{ Local well name } & \multirow{2}{*}{$\begin{array}{c}\text { Well } \\
\text { number }\end{array}$} & \multirow{2}{*}{$\begin{array}{l}\text { Aquifer } \\
\text { code }\end{array}$} & \multirow{2}{*}{$\begin{array}{c}\text { Altitude of } \\
\text { land surface } \\
\text { (feet above } \\
\text { NGVD 1929) }\end{array}$} & \multicolumn{2}{|c|}{$\begin{array}{c}\text { Open interval } \\
\text { (feet below land } \\
\text { surface) }\end{array}$} & \multirow{2}{*}{$\begin{array}{l}\text { NJDEP } \\
\text { permit } \\
\text { number }\end{array}$} & \multirow{2}{*}{$\begin{array}{c}1996 \\
\text { withdrawals } \\
\text { (Mgal/yr) }\end{array}$} \\
\hline & & & & & & Top & Bottom & & \\
\hline \multicolumn{10}{|c|}{ Salem County } \\
\hline 84 & ATL CITY ELEC & DEEPWATER 3R & $33-122$ & MRPAM & 10 & 165 & 235 & $30-01234$ & 8.294 \\
\hline 85 & ATL CITY ELEC & DEEPWATER 2 & $33-123$ & MRPAM & 10 & 157 & 234 & $50-00001$ & 15.351 \\
\hline 86 & ATL CITY ELEC & DEEPWATER 5 & $33-125$ & MRPAM & 10 & 149 & 219 & $30-00151$ & 11.403 \\
\hline 87 & $\begin{array}{l}\text { ATLANTIC CITY ELEC CO - } \\
\text { DEEPWATER STA }\end{array}$ & AC ELEC IW-3R & $33-897$ & MRPAM & 5 & 189 & 229 & 30-08099 & 59.371 \\
\hline 88 & B F GOODRICH CO & $6(\mathrm{PW}-2)$ & $33-85$ & MRPAM & 10 & 109 & 129 & $30-01141$ & 186.336 \\
\hline 89 & B F GOODRICH CO & $4(\mathrm{PW}-3)$ & $33-86$ & MRPAL & 13 & 169 & 189 & $30-01139$ & 123.259 \\
\hline 90 & B F GOODRICH CO & 3 & $33-432$ & MRPAL & 10 & 180 & 195 & $50-00079$ & 7.261 \\
\hline 91 & E I DUPONT & CHAMBERS INJ 1 & $33-129$ & MRPAM & 8 & -- & -- & $30-01018$ & 73.98 \\
\hline 92 & E I DUPONT & DRINKWATER 8 & $33-137$ & MRPAL & 14 & 317 & 347 & $50-00003$ & .009 \\
\hline 93 & E I DUPONT & CHAMBERS INJ 3 & $33-138$ & MRPAL & 5 & 314 & 462 & $30-01049$ & .018 \\
\hline 94 & E I DUPONT & 102 & $33-316$ & MRPAU & 5 & -- & -- & $30-02322$ & 8.053 \\
\hline 95 & E I DUPONT & 104 & $33-319$ & MRPAM & 5 & -- & -- & $30-01272$ & 59.738 \\
\hline 96 & E I DUPONT & CARNEY PT 2 & $33-322$ & MRPAM & 5 & 169 & 219 & $50-00004$ & 17.87 \\
\hline 97 & E I DUPONT & CARNEY PT 4 & $33-326$ & MRPAU & 5 & -- & -- & $30-00423$ & 4.505 \\
\hline 98 & E I DUPONT & CHAMBERS 108 & $33-602$ & MRPAM & 5 & 43.1 & 86.2 & $30-03368$ & 164.032 \\
\hline 99 & E I DUPONT & DUPONT REPL 103A & $33-857$ & MRPAM & 5 & 49 & 81 & $30-03367$ & 204.242 \\
\hline 100 & E I DUPONT & CHAMBERS 5-R & $33-898$ & MRPAM & 5 & 81 & 119 & $30-04667$ & 189.264 \\
\hline 101 & GEON COMPANY & BFG SHALLOW WELL 10 & $33-784$ & MRPAM & 10 & 76 & 102 & $30-06023$ & 13.406 \\
\hline 102 & PEDRICKTOWN COGENERATION LTD & PEDRICKTOWN PW-3 & 33-899 & MRPAL & 15 & 170 & 195 & $30-08172$ & 94.044 \\
\hline 103 & PEDRICKTOWN COGENERATION LTD & PEDRICKTOWN PW-1 & $33-901$ & MRPAL & 15 & 207 & 248 & $30-07176$ & 46.141 \\
\hline 104 & PEDRICKTOWN COGNERATION LTD & PEDRICKTOWN PW-2 & $33-900$ & MRPAL & 10 & 215 & 235 & $30-07824$ & 5.159 \\
\hline 105 & PENNS GROVE WATER CO & RF 3A & $33-750$ & MRPAU & 20 & 36 & 56 & $30-03535$ & 84.277 \\
\hline 106 & PENNS GROVE WATER SUPPLY CO & LAYTON 2 & $33-697$ & MRPAU & 12 & 47 & 62 & $30-01113$ & 88.69 \\
\hline
\end{tabular}


Table 1. Locations of, construction data for, and withdrawals from wells capable of withdrawing more than 100,000 gallons per day that are within 2 miles of the Delaware River in Camden, Gloucester, and Salem Counties, N.J.-Continued

[NJDEP, New Jersey Department of Environmental Protection; Mgal/yr, million gallons per year; --, no data; Aquifer codes: QRNR, Quaternary deposits; HPPN, undifferentiated Holocene, Pleistocene,

Pliocene, and (or) Miocene deposits; MLRW, Wenonah-Mt. Laurel aquifer; MRPA, Potomac-Raritan-Magothy undifferentiated; MRPAU, Upper Potomac-Raritan-Magothy aquifer; MRPAM, Middle PotomacRaritan-Magothy aquifer; MRPAL, Lower Potomac-Raritan-Magothy aquifer]

\begin{tabular}{|c|c|c|c|c|c|c|c|c|c|}
\hline \multirow{2}{*}{$\begin{array}{c}\text { Map } \\
\text { number } \\
\text { of well in } \\
\text { figure } 1\end{array}$} & \multirow[t]{2}{*}{ Well owner } & \multirow[t]{2}{*}{ Local well name } & \multirow{2}{*}{$\begin{array}{c}\text { Well } \\
\text { number }\end{array}$} & \multirow{2}{*}{$\begin{array}{l}\text { Aquifer } \\
\text { code }\end{array}$} & \multirow{2}{*}{$\begin{array}{c}\text { Altitude of } \\
\text { land surface } \\
\text { (feet above } \\
\text { NGVD 1929) }\end{array}$} & \multicolumn{2}{|c|}{$\begin{array}{c}\text { Open interval } \\
\text { (feet below land } \\
\text { surface) }\end{array}$} & \multirow{2}{*}{$\begin{array}{l}\text { NJDEP } \\
\text { permit } \\
\text { number }\end{array}$} & \multirow{2}{*}{$\begin{array}{c}1996 \\
\text { withdrawals } \\
\text { (Mgal/yr) }\end{array}$} \\
\hline & & & & & & Top & Bottom & & \\
\hline \multicolumn{10}{|c|}{ Salem County--Continued } \\
\hline 107 & PENNS GROVE WSC & LAYTON 11 & $33-330$ & MRPAL & 16 & - & -- & $50-00098$ & 53.839 \\
\hline 108 & PENNS GROVE WSC & LAYNE 1 & $33-346$ & MRPAL & 19 & 317 & 357 & $30-00563$ & 169.989 \\
\hline 109 & PENNS GROVE WSC & SCHULTES 4 & $33-361$ & MRPAU & 13 & 44 & 54 & $30-01815$ & 88.69 \\
\hline 110 & PENNS GROVE WSC & PGWSC 1A/RF2A & $33-460$ & MRPAU & 19 & 41 & 61 & $30-03310$ & 65.303 \\
\hline 111 & PENNS GROVE WSC & $\begin{array}{l}\text { RTE } 48 \text { \& DUPONT RD } \\
\text { RF2B }\end{array}$ & $33-767$ & MRPAU & 20 & 50 & 65 & $30-08511$ & 0.332 \\
\hline 112 & PENNSVILLE T WD & PTWD 1 & $33-118$ & MRPAM & 8 & 213 & 238 & $50-00041$ & 31.925 \\
\hline 113 & PENNSVILLE T WD & PTWD 2 & $33-119$ & MRPAM & 7 & 210 & 230 & $30-00018$ & 46.987 \\
\hline 114 & PENNSVILLE T WD & PTWD 5 & $33-360$ & MRPAU & 10 & 101 & 117 & $28-10466$ & 87.094 \\
\hline 115 & PENNSVILLE T WD & PTWD 6 & $33-453$ & MRPAU & 10 & 99 & 114 & $30-03013$ & 9.299 \\
\hline 116 & PENNSVILLE T WD & PTWD 3A & $33-671$ & MRPAU & 7 & 87 & 102 & $30-05148$ & 79.827 \\
\hline 117 & PENNSVILLE TWP & PTWD 4A RPL & $33-686$ & MRPAU & 10 & 110 & 130 & $30-08335$ & 68.79 \\
\hline 118 & PUBLIC SERV E-G & PW 3 & $33-32$ & MLRW & 12 & 242 & 293 & $34-00758$ & .054 \\
\hline 119 & PUBLIC SERV E-G & PW 2 & $33-35$ & MLRW & 9 & 230 & 281 & $34-00757$ & .009 \\
\hline 120 & PUBLIC SERV E-G & PW 5 & $33-364$ & MRPAM & 17 & 765 & 840 & 34-01031 & 38.475 \\
\hline 121 & PUBLIC SERV E-G & HOPE CREEK & $33-452$ & MRPAM & 10 & 746 & 817 & $34-01074$ & 20.925 \\
\hline \multirow[t]{3}{*}{122} & SIEGFRIED CHEM & 1973-1 & 33-109 & MRPAU & 5 & 116 & 131 & $30-01322$ & 4.454 \\
\hline & & & & & & & & Total & $2,230.695$ \\
\hline & & & & & & & TOTAL & & $12,220.935$ \\
\hline
\end{tabular}


Table 2. Saltwater-intrusion vulnerability characteristics of wells capable of withdrawing more than 100,000 gallons per day that are within 2 miles of the Delaware River in Camden and Gloucester Counties, N.J.

[Mgal/yr, million gallons per year; mg/L, milligrams per liter; Aquifer codes: QRNR, Quaternary deposits; HPPN, undifferentiated Holocene, Pleistocene, Pliocene, and (or) Miocene deposits; MLRW, WenonahMt. Laurel aquifer; MRPA, Potomac-Raritan-Magothy undifferentiated; MRPAU, Upper Potomac-Raritan-Magothy aquifer; MRPAM, Middle Potomac-Raritan-Magothy aquifer; MRPAL, Lower Potomac-Raritan-Magothy aquifer.]

\begin{tabular}{|c|c|c|c|c|c|c|c|c|c|c|c|c|c|}
\hline \multirow{3}{*}{$\begin{array}{l}\text { Map } \\
\text { number } \\
\text { of well } \\
\text { in } \\
\text { figure } 1\end{array}$} & \multirow{3}{*}{ Well owner } & \multirow{3}{*}{ Local well name } & \multirow{3}{*}{ Aquifer } & \multirow{3}{*}{$\begin{array}{c}\text { Model } \\
\text { row }\end{array}$} & \multirow{3}{*}{$\begin{array}{l}\text { Model } \\
\text { column }\end{array}$} & \multirow{3}{*}{$\begin{array}{c}1996 \\
\text { withdrawals } \\
\text { (Mgal/yr) }\end{array}$} & \multirow{3}{*}{$\begin{array}{c}\text { Percent } \\
\text { of well } \\
\text { water } \\
\text { derived } \\
\text { from } \\
\text { river }\end{array}$} & \multicolumn{3}{|c|}{ Isolated 1-month event } & \multicolumn{3}{|c|}{ Annually recurring 1-month } \\
\hline & & & & & & & & \multirow{2}{*}{$\begin{array}{c}\text { Percent } \\
\text { of initial } \\
\text { river } \\
\text { concen- } \\
\text { tration } \\
\text { at well }\end{array}$} & \multicolumn{2}{|c|}{$\begin{array}{l}\text { Concentration } \\
\text { threshold in river } \\
\text { resulting in } \\
\text { nonpotability }\end{array}$} & \multirow{2}{*}{$\begin{array}{c}\text { Percent } \\
\text { of initial } \\
\text { river } \\
\text { concen- } \\
\text { tration at } \\
\text { well }\end{array}$} & \multicolumn{2}{|c|}{$\begin{array}{c}\text { Concentration } \\
\text { threshold in river } \\
\text { resulting in } \\
\text { nonpotability }\end{array}$} \\
\hline & & & & & & & & & $\begin{array}{c}\text { Chloride } \\
\text { (mg/L) }\end{array}$ & $\begin{array}{c}\text { Sodium } \\
\text { (mg/L) }\end{array}$ & & $\begin{array}{c}\text { Chloride } \\
\text { (mg/L) }\end{array}$ & $\begin{array}{c}\text { Sodium } \\
\text { (mg/L) }\end{array}$ \\
\hline \multicolumn{14}{|c|}{ High-vulnerability wells } \\
\hline 7 & CAMDEN CITY W D & DELAIR 1 & MRPAL & 19 & 67 & 333.875 & 81 & 8 & 3,799 & 713 & 11 & 2,763 & 519 \\
\hline 8 & CAMDEN CITY W D & DELAIR 2 & MRPAL & 19 & 67 & 333.875 & 81 & 8 & 3,799 & 713 & 11 & 2,763 & 519 \\
\hline 9 & CAMDEN CITY W D & DELAIR 3 & MRPAL & 19 & 67 & 333.875 & 81 & 8 & 3,799 & 713 & 11 & 2,763 & 519 \\
\hline 10 & CAMDEN CITY W D & MORRIS 6 & MRPAL & 20 & 69 & 333.875 & 54 & 2 & 22,296 & 3,778 & 2 & 22,296 & 3,778 \\
\hline 11 & CAMDEN CITY W D & MORRIS 9 & MRPAL & 20 & 69 & 333.875 & 54 & 2 & 22,296 & 3,778 & 2 & 22,296 & 3,778 \\
\hline 12 & CAMDEN CITY W D & MORRIS 8 & MRPAL & 20 & 69 & 333.875 & 54 & 2 & 22,296 & 3,778 & 2 & 22,296 & 3,778 \\
\hline 13 & CAMDEN CITY W D & MORRIS 7 & MRPAL & 19 & 70 & 333.875 & 76 & 3.5 & 9,218 & 1,699 & 7 & 4,609 & 850 \\
\hline 14 & CAMDEN CITY W D & MORRIS 10 & MRPAL & 19 & 70 & 333.875 & 76 & 3.5 & 9,218 & 1,699 & 7 & 4,609 & 850 \\
\hline 15 & CAMDEN CITY W D & MORRIS 3A & MRPAL & 20 & 71 & 333.875 & 93 & 2 & 13,366 & 2,613 & 2 & 13,366 & 2,613 \\
\hline 18 & CAMDEN CITY W D & MORRIS 11 & MRPAL & 19 & 68 & 333.875 & 91 & 13 & 2,098 & 407 & 15 & 1,818 & 353 \\
\hline 19 & CAMDEN CITY W D & MORRIS 12 & MRPAL & 19 & 69 & 333.875 & 86 & 10 & 2,874 & 549 & 12 & 2,395 & 457 \\
\hline 20 & CAMDEN CITY W D & MORRIS 13 & MRPAL & 19 & 68 & 333.875 & 91 & 13 & 2,098 & 407 & 15 & 1,818 & 353 \\
\hline \multicolumn{14}{|c|}{ Low-vulnerability wells } \\
\hline 1 & BELLMAWR B W D & BBWD 3 & MRPAL & 42 & 45 & 28.919 & 40 & & & & & & \\
\hline 21 & GLOUCESTER C WD & GCWD 42 & MRPAL & 34 & 48 & 17.547 & 42 & & & & & & \\
\hline 22 & GLOUCESTER C WD & GCWD 40 & MRPAL & 34 & 48 & 149.51 & 42 & & & & & & \\
\hline 23 & GLOUCESTER C WD & GCWD 43 & MRPAL & 34 & 48 & 53.152 & 42 & & & & & & \\
\hline 25 & MACANDREWS \& FORBES CO & $\mathrm{M} \& \mathrm{~F}$ IND 3R & MRPAM & 24 & 51 & 33.402 & 42 & & & & & & \\
\hline 26 & MAFCO & MAFCO 4R/1 & MRPAM & 25 & 51 & 10.061 & 43 & & & & & & \\
\hline
\end{tabular}


Table 2. Saltwater-intrusion vulnerability characteristics of wells capable of withdrawing more than 100,000 gallons per day that are within 2 miles of the Delaware River in Camden and Gloucester Counties, N.J.-Continued

[Mgal/yr, million gallons per year; mg/L, milligrams per liter; Aquifer codes: QRNR, Quaternary deposits; HPPN, undifferentiated Holocene, Pleistocene, Pliocene, and (or) Miocene deposits; MLRW, WenonahMt. Laurel aquifer; MRPA, Potomac-Raritan-Magothy undifferentiated; MRPAU, Upper Potomac-Raritan-Magothy aquifer; MRPAM, Middle Potomac-Raritan-Magothy aquifer; MRPAL, Lower Potomac-Raritan-Magothy aquifer.]

\begin{tabular}{|c|c|c|c|c|c|c|c|c|c|c|c|c|c|}
\hline \multirow{3}{*}{$\begin{array}{c}\text { Map } \\
\text { number } \\
\text { of well } \\
\text { in } \\
\text { figure } 1\end{array}$} & \multirow{3}{*}{ Well owner } & \multirow{3}{*}{ Local well name } & \multirow{3}{*}{ Aquifer } & \multirow{3}{*}{$\begin{array}{c}\text { Model } \\
\text { row }\end{array}$} & \multirow{3}{*}{$\begin{array}{l}\text { Model } \\
\text { column }\end{array}$} & \multirow{3}{*}{$\begin{array}{c}1996 \\
\text { withdrawals } \\
\text { (Mgal/yr) }\end{array}$} & \multirow{3}{*}{$\begin{array}{l}\text { Percent } \\
\text { of well } \\
\text { water } \\
\text { derived } \\
\text { from } \\
\text { river }\end{array}$} & \multicolumn{3}{|c|}{ Isolated 1-month event } & \multicolumn{3}{|c|}{ Annually recurring 1-month } \\
\hline & & & & & & & & \multirow{2}{*}{$\begin{array}{c}\text { Percent } \\
\text { of initial } \\
\text { river } \\
\text { concen- } \\
\text { tration } \\
\text { at well }\end{array}$} & \multicolumn{2}{|c|}{$\begin{array}{l}\text { Concentration } \\
\text { threshold in river } \\
\text { resulting in } \\
\text { nonpotability }\end{array}$} & \multirow{2}{*}{$\begin{array}{c}\text { Percent } \\
\text { of initial } \\
\text { river } \\
\text { concen- } \\
\text { tration at } \\
\text { well }\end{array}$} & \multicolumn{2}{|c|}{$\begin{array}{l}\text { Concentration } \\
\text { threshold in river } \\
\text { resulting in } \\
\text { nonpotability }\end{array}$} \\
\hline & & & & & & & & & $\begin{array}{c}\text { Chloride } \\
\text { (mg/L) }\end{array}$ & $\begin{array}{c}\text { Sodium } \\
\text { (mg/L) }\end{array}$ & & $\begin{array}{c}\text { Chloride } \\
\text { (mg/L) }\end{array}$ & $\begin{array}{c}\text { Sodium } \\
\text { (mg/L) }\end{array}$ \\
\hline
\end{tabular}

\begin{tabular}{|c|c|c|c|c|c|c|c|}
\hline \multicolumn{8}{|c|}{ Low-vulnerability wells--Continued } \\
\hline 32 & MCHVIL PNSK WCM & NATIONAL HWY 2 & MRPAL & 25 & 73 & 306.04 & 46 \\
\hline 35 & NJ/AMERICAN WATER CO & 54 & MRPAL & 22 & 62 & 154.655 & 75 \\
\hline 38 & BP OIL CO & BP R-6-A & MRPAM & 22 & 26 & 40.234 & 89 \\
\hline 39 & BP OIL CO & BP R-8-A & MRPAM & 22 & 26 & 16.489 & 89 \\
\hline 40 & BP OIL CO & BP R-9-A & MRPAM & 23 & 25 & 17.349 & 41 \\
\hline 41 & BP OIL CO & BP R-7-A & MRPAM & 21 & 26 & 16.022 & 95 \\
\hline 42 & $\begin{array}{l}\text { BP OIL COMPANY - } \\
\text { PAULSBORO TERMINAL }\end{array}$ & BP R-4A & HPPM & 23 & 25 & 19.921 & 41 \\
\hline 43 & $\begin{array}{l}\text { BP OIL COMPANY - } \\
\text { PAULSBORO TERMINAL }\end{array}$ & BP R-10A & HРPM & 22 & 26 & 7.204 & 89 \\
\hline 44 & $\begin{array}{l}\text { BP OIL COMPANY - } \\
\text { SOHIO PAULSBORO }\end{array}$ & BP 51-1 & HРPM & 22 & 26 & 0.178 & 89 \\
\hline 45 & $\begin{array}{l}\text { BP OIL COMPANY - } \\
\text { SOHIO PAULSBORO }\end{array}$ & BP RECOVERY 2 & HРPM & 22 & 26 & 7.004 & 89 \\
\hline 46 & $\begin{array}{l}\text { COASTAL EAGLE POINT OIL } \\
\text { COMPANY }\end{array}$ & EAGLE POINT 7 & MRPAL & 32 & 38 & 140.319 & 60 \\
\hline 49 & $\begin{array}{l}\text { COASTAL EAGLE POINT OIL } \\
\text { COMPANY }\end{array}$ & EAGLE POINT 6A & MRPAL & 33 & 38 & 222.526 & 70 \\
\hline 60 & MOBIL OIL COMPANY & MOBIL 47 & MRPAL & 21 & 24 & 3.405 & 50 \\
\hline 61 & MOBIL OIL COMPANY & RW-5 & QRNR & 21 & 24 & 22.869 & 50 \\
\hline 62 & MOBIL OIL COMPANY & RW-6 & QRNR & 21 & 24 & 50.047 & 50 \\
\hline 69 & NATIONAL PK W D & NPWD 2/NPWD 5 & MRPAL & 29 & 35 & 48.195 & 90 \\
\hline
\end{tabular}


Table 2. Saltwater-intrusion vulnerability characteristics of wells capable of withdrawing more than 100,000 gallons per day that are within 2 miles of the Delaware River in Camden and Gloucester Counties, N.J.-Continued

[Mgal/yr, million gallons per year; mg/L, milligrams per liter; Aquifer codes: QRNR, Quaternary deposits; HPPN, undifferentiated Holocene, Pleistocene, Pliocene, and (or) Miocene deposits; MLRW, WenonahMt. Laurel aquifer; MRPA, Potomac-Raritan-Magothy undifferentiated; MRPAU, Upper Potomac-Raritan-Magothy aquifer; MRPAM, Middle Potomac-Raritan-Magothy aquifer; MRPAL, Lower Potomac-Raritan-Magothy aquifer.]

\begin{tabular}{|c|c|c|c|c|c|c|c|c|c|c|c|c|c|}
\hline \multirow{3}{*}{$\begin{array}{c}\text { Map } \\
\text { number } \\
\text { of well } \\
\text { in } \\
\text { figure } 1\end{array}$} & \multirow{3}{*}{ Well owner } & \multirow{3}{*}{ Local well name } & \multirow{3}{*}{ Aquifer } & \multirow{3}{*}{$\begin{array}{l}\text { Model } \\
\text { row }\end{array}$} & \multirow{3}{*}{$\begin{array}{l}\text { Model } \\
\text { column }\end{array}$} & \multirow{3}{*}{$\begin{array}{c}1996 \\
\text { withdrawals } \\
\text { (Mgal/yr) }\end{array}$} & \multirow{3}{*}{$\begin{array}{c}\text { Percent } \\
\text { of well } \\
\text { water } \\
\text { derived } \\
\text { from } \\
\text { river }\end{array}$} & \multicolumn{3}{|c|}{ Isolated 1-month event } & \multicolumn{3}{|c|}{ Annually recurring 1-month } \\
\hline & & & & & & & & \multirow{2}{*}{$\begin{array}{c}\text { Percent } \\
\text { of initial } \\
\text { river } \\
\text { concen- } \\
\text { tration } \\
\text { at well }\end{array}$} & \multicolumn{2}{|c|}{$\begin{array}{c}\text { Concentration } \\
\text { threshold in river } \\
\text { resulting in } \\
\text { nonpotability }\end{array}$} & \multirow{2}{*}{$\begin{array}{c}\text { Percent } \\
\text { of initial } \\
\text { river } \\
\text { concen- } \\
\text { tration at } \\
\text { well }\end{array}$} & \multicolumn{2}{|c|}{$\begin{array}{c}\text { Concentration } \\
\text { threshold in river } \\
\text { resulting in } \\
\text { nonpotability }\end{array}$} \\
\hline & & & & & & & & & $\begin{array}{c}\text { Chloride } \\
\text { (mg/L) }\end{array}$ & $\begin{array}{c}\text { Sodium } \\
\text { (mg/L) }\end{array}$ & & $\begin{array}{c}\text { Chloride } \\
\text { (mg/L) }\end{array}$ & $\begin{array}{c}\text { Sodium } \\
\text { (mg/L) }\end{array}$ \\
\hline \multicolumn{14}{|c|}{ Low-vulnerability wells--Continued } \\
\hline 70 & NATIONAL PK W D & NPWD 6 & MRPAL & 29 & 35 & 66.433 & 90 & & & & & & \\
\hline 73 & PAULSBORO W D & PWD 5 & MRPAM & 28 & 23 & 114.423 & 43 & & & & & & \\
\hline 76 & PENNWALT CORP & 418 & MRPAL & 30 & 28 & 7.29 & 74 & & & & & & \\
\hline 77 & PENNWALT CORP & 417 & MRPAL & 30 & 29 & 288.57 & 56 & & & & & & \\
\hline 80 & W DEPTFORD T WD & WDTWD 7 & MRPAL & 38 & 38 & 216.473 & 61 & & & & & & \\
\hline 81 & WESTVILLE W D & WWD 5 & MRPAL & 39 & 43 & 141.34 & 50 & & & & & & \\
\hline \multicolumn{14}{|c|}{ Wells with no vulnerability } \\
\hline 2 & BELLMAWR B W D & BBWD 6 & MRPAL & 44 & 46 & 45.456 & 33 & & & & & & \\
\hline 3 & BROOKLAWN B W D & BBWD 3 & MRPAL & 36 & 45 & 23.367 & 0 & & & & & & \\
\hline 4 & BROOKLAWN B W D & BBWD 5(OW 3) & MRPAL & 37 & 45 & 25.492 & 11 & & & & & & \\
\hline 5 & BROOKLAWN B W D & BBWD 4 & MRPAL & 36 & 43 & 58.2 & 19 & & & & & & \\
\hline 6 & CAMDEN CITY W D & CITY 11 & MRPAM & 27 & 52 & 11.81 & 0 & & & & & & \\
\hline 16 & CAMDEN CITY W D & MORRIS 1 & MRPAL & 20 & 73 & 333.875 & 0 & & & & & & \\
\hline 17 & CAMDEN CITY W D & PARKSIDE 18 & MRPAL & 28 & 56 & 201.84 & 34 & & & & & & \\
\hline 24 & GLOUCESTER CITY & $\begin{array}{l}\text { GCWD 41/AKA } \\
3104903 \text { RD }\end{array}$ & MRPAU & 33 & 49 & 207.447 & 15 & & & & & & \\
\hline 27 & MCHVIL PNSK WCM & $1 \mathrm{R}$ & MRPAM & 30 & 61 & 277.867 & 3 & & & & & & \\
\hline 28 & MCHVIL PNSK WCM & WOODBINE 1 & MRPAL & 31 & 64 & 47.744 & 14 & & & & & & \\
\hline 29 & MCHVIL PNSK WCM & MARION 1 & MRPAL & 31 & 66 & 139.934 & 11 & & & & & & \\
\hline 30 & MCHVIL PNSK WCM & NATIONAL HWY 1 & MRPAL & 25 & 72 & 0.271 & 0 & & & & & & \\
\hline 31 & MCHVIL PNSK WCM & WOODBINE 2 & MRPAL & 31 & 64 & 66.769 & 14 & & & & & & \\
\hline 33 & NEW JERSEY WATER CO & $\begin{array}{l}\text { CLEVELAND AVE } \\
\text { PW } 53\end{array}$ & MRPAL & 22 & 61 & 120.404 & 24 & & & & & & \\
\hline
\end{tabular}


Table 2. Saltwater-intrusion vulnerability characteristics of wells capable of withdrawing more than 100,000 gallons per day that are within 2 miles of the Delaware River in

Camden and Gloucester Counties, N.J.-Continued

[Mgal/yr, million gallons per year; mg/L, milligrams per liter; Aquifer codes: QRNR, Quaternary deposits; HPPN, undifferentiated Holocene, Pleistocene, Pliocene, and (or) Miocene deposits; MLRW, WenonahMt. Laurel aquifer; MRPA, Potomac-Raritan-Magothy undifferentiated; MRPAU, Upper Potomac-Raritan-Magothy aquifer; MRPAM, Middle Potomac-Raritan-Magothy aquifer; MRPAL, Lower Potomac-Raritan-Magothy aquifer.]

\begin{tabular}{|c|c|c|c|c|c|c|c|c|c|c|c|c|c|}
\hline \multirow{3}{*}{$\begin{array}{c}\text { Map } \\
\text { number } \\
\text { of well } \\
\text { in } \\
\text { figure 1 }\end{array}$} & \multirow{3}{*}{ Well owner } & \multirow{3}{*}{ Local well name } & \multirow{3}{*}{ Aquifer } & \multirow{3}{*}{$\begin{array}{l}\text { Model } \\
\text { row }\end{array}$} & \multirow{3}{*}{$\begin{array}{l}\text { Model } \\
\text { column }\end{array}$} & \multirow{3}{*}{$\begin{array}{c}1996 \\
\text { withdrawals } \\
\text { (Mgal/yr) }\end{array}$} & \multirow{3}{*}{$\begin{array}{c}\text { Percent } \\
\text { of well } \\
\text { water } \\
\text { derived } \\
\text { from } \\
\text { river }\end{array}$} & \multicolumn{3}{|c|}{ Isolated 1-month event } & \multicolumn{3}{|c|}{ Annually recurring 1-month } \\
\hline & & & & & & & & \multirow{2}{*}{$\begin{array}{l}\text { Percent } \\
\text { of initial } \\
\text { river } \\
\text { concen- } \\
\text { tration } \\
\text { at well }\end{array}$} & \multicolumn{2}{|c|}{$\begin{array}{l}\text { Concentration } \\
\text { threshold in river } \\
\text { resulting in } \\
\text { nonpotability }\end{array}$} & \multirow{2}{*}{$\begin{array}{c}\text { Percent } \\
\text { of initial } \\
\text { river } \\
\text { concen- } \\
\text { tration at } \\
\text { well }\end{array}$} & \multicolumn{2}{|c|}{$\begin{array}{l}\text { Concentration } \\
\text { threshold in river } \\
\text { resulting in } \\
\text { nonpotability }\end{array}$} \\
\hline & & & & & & & & & $\begin{array}{l}\text { Chloride } \\
\text { (mg/L) }\end{array}$ & $\begin{array}{l}\text { Sodium } \\
\text { (mg/L) }\end{array}$ & & $\begin{array}{l}\text { Chloride } \\
\text { (mg/L) }\end{array}$ & $\begin{array}{c}\text { Sodium } \\
\text { (mg/L) }\end{array}$ \\
\hline \multicolumn{14}{|c|}{ Wells with no vulnerability--Continued } \\
\hline 34 & NJ/AMERICAN WATER CO & CAMDEN DIV 52 & MRPAL & 22 & 60 & 204.04 & 3 & & & & & & \\
\hline 36 & NJ/AMERICAN WATER CO & 55 & MRPAL & 22 & 60 & 5.498 & 3 & & & & & & \\
\hline 37 & OUR LADY HOSP & STAND BY WELL & MRPAL & 28 & 55 & 0.01 & 0 & & & & & & \\
\hline 47 & $\begin{array}{l}\text { COASTAL EAGLE POINT OIL } \\
\text { COMPANY }\end{array}$ & EAGLE POINT 1 & MRPAL & 33 & 40 & 85.453 & 14 & & & & & & \\
\hline 48 & $\begin{array}{l}\text { COASTAL EAGLE POINT OIL } \\
\text { COMPANY }\end{array}$ & EAGLE POINT & MRPAL & 32 & 40 & 73.697 & 1 & & & & & & \\
\hline 50 & E I DUPONT & REPAUNO 3 & MRPAM & 16 & 16 & 151.512 & 0 & & & & & & \\
\hline 51 & E I DUPONT & REPAUNO 6 & MRPAM & 16 & 17 & 25.648 & 0 & & & & & & \\
\hline 52 & E I DUPONT & INTERCEPTOR 46 & MRPAM & 16 & 17 & 162.461 & 0 & & & & & & \\
\hline 53 & GREENWICH T W D & GTWD 5 (2-A) & MRPAM & 18 & 17 & 137.675 & 0 & & & & & & \\
\hline 54 & GREENWICH T W D & GTWD 6 & MRPAM & 26 & 19 & 103.554 & 0 & & & & & & \\
\hline 55 & $\begin{array}{l}\text { GREENWICH TWP WATER } \\
\text { DEPT }\end{array}$ & MEMORIAL AVE 4R & MRPAM & 23 & 21 & 107.177 & 0 & & & & & & \\
\hline 56 & HERCULES CHEMICAL & 41970 & MRPAM & 18 & 17 & 25.389 & 0 & & & & & & \\
\hline 57 & HERCULES INC & HERCULES PW 11 & MRPAM & 21 & 17 & 51.364 & 0 & & & & & & \\
\hline 58 & $\begin{array}{l}\text { HERCULES INC - HIGGINS } \\
\text { PLANT }\end{array}$ & HERCULES PW-10 & MRPAM & 19 & 18 & 9.773 & 0 & & & & & & \\
\hline 59 & LOGAN WELLS WATER CO & $\begin{array}{l}\text { LWWC BIRCH CK } \\
\text { RD } 4\end{array}$ & MRPAM & 14 & 3 & 85.095 & 0 & & & & & & \\
\hline 63 & MOBIL OIL COMPANY & $\mathrm{RW}-8$ & QRNR & 22 & 23 & 5.973 & 0 & & & & & & \\
\hline 64 & MOBIL OIL COMPANY & MOBIL 48 DWTA & MRPAM & 23 & 22 & 90.081 & 8 & & & & & & \\
\hline 65 & MOBIL OIL COMPANY & MOBIL RW-19 & MRPAM & 23 & 22 & 140.96 & 8 & & & & & & \\
\hline
\end{tabular}


Table 2. Saltwater-intrusion vulnerability characteristics of wells capable of withdrawing more than 100,000 gallons per day that are within 2 miles of the Delaware River in Camden and Gloucester Counties, N.J.—Continued

[Mgal/yr, million gallons per year; mg/L, milligrams per liter; Aquifer codes: QRNR, Quaternary deposits; HPPN, undifferentiated Holocene, Pleistocene, Pliocene, and (or) Miocene deposits; MLRW, WenonahMt. Laurel aquifer; MRPA, Potomac-Raritan-Magothy undifferentiated; MRPAU, Upper Potomac-Raritan-Magothy aquifer; MRPAM, Middle Potomac-Raritan-Magothy aquifer; MRPAL, Lower Potomac-Raritan-Magothy aquifer.]

\begin{tabular}{|c|c|c|c|c|c|c|c|c|c|c|c|c|c|}
\hline \multirow{3}{*}{$\begin{array}{c}\text { Map } \\
\text { number } \\
\text { of well } \\
\text { in } \\
\text { figure } 1\end{array}$} & \multirow{3}{*}{ Well owner } & \multirow{3}{*}{ Local well name } & \multirow{3}{*}{ Aquifer } & \multirow{3}{*}{$\begin{array}{l}\text { Model } \\
\text { row }\end{array}$} & \multirow{3}{*}{$\begin{array}{l}\text { Model } \\
\text { column }\end{array}$} & \multirow{3}{*}{$\begin{array}{c}1996 \\
\text { withdrawals } \\
\text { (Mgal/yr) }\end{array}$} & \multirow{3}{*}{$\begin{array}{l}\text { Percent } \\
\text { of well } \\
\text { water } \\
\text { derived } \\
\text { from } \\
\text { river }\end{array}$} & \multicolumn{3}{|c|}{ Isolated 1-month event } & \multicolumn{3}{|c|}{ Annually recurring 1-month } \\
\hline & & & & & & & & \multirow{2}{*}{$\begin{array}{c}\text { Percent } \\
\text { of initial } \\
\text { river } \\
\text { concen- } \\
\text { tration } \\
\text { at well }\end{array}$} & \multicolumn{2}{|c|}{$\begin{array}{l}\text { Concentration } \\
\text { threshold in river } \\
\text { resulting in } \\
\text { nonpotability }\end{array}$} & \multirow{2}{*}{$\begin{array}{c}\text { Percent } \\
\text { of initial } \\
\text { river } \\
\text { concen- } \\
\text { tration at } \\
\text { well }\end{array}$} & \multicolumn{2}{|c|}{$\begin{array}{c}\text { Concentration } \\
\text { threshold in river } \\
\text { resulting in } \\
\text { nonpotability }\end{array}$} \\
\hline & & & & & & & & & $\begin{array}{c}\text { Chloride } \\
\text { (mg/L) }\end{array}$ & $\begin{array}{l}\text { Sodium } \\
\text { (mg/L) }\end{array}$ & & $\begin{array}{l}\text { Chloride } \\
\text { (mg/L) }\end{array}$ & $\begin{array}{c}\text { Sodium } \\
\text { (mg/L) }\end{array}$ \\
\hline \multicolumn{14}{|c|}{ Wells with no vulnerability--Continued } \\
\hline 66 & MONSANTO CHEM & BRIDGEPORT W2 & MRPAM & 7 & 3 & 200.006 & 17 & & & & & & \\
\hline 67 & MONSANTO CHEM & BRIDGEPORT E1 & MRPAM & 7 & 3 & 59.579 & 17 & & & & & & \\
\hline 68 & MONSANTO CHEM & MONSANTO 1 & MRPAM & 8 & 3 & 107.841 & 0 & & & & & & \\
\hline 71 & PAULSBORO W D & Jun-73 & MRPAM & 30 & 22 & 111.811 & 3 & & & & & & \\
\hline 72 & PAULSBORO W D & PWD 4 & MRPAM & 27 & 21 & 53.828 & 0 & & & & & & \\
\hline 74 & PENNS GROVE WATER CO & $\begin{array}{l}\text { BRIDGEPORT } \\
\text { BACKUP-2 }\end{array}$ & MRPAM & 13 & 8 & 4.899 & 0 & & & & & & \\
\hline 75 & PENNS GROVE WSC & BRIDGEPORT 2 & MRPAM & 13 & 8 & 31.818 & 0 & & & & & & \\
\hline 78 & TEXAS OIL CO & EAGLE POINT 4A & MRPAL & 32 & 39 & 1.908 & 3 & & & & & & \\
\hline 79 & W DEPTFORD T WD & 6 RED BANK AVE & MRPAL & 37 & 36 & 135.476 & 36 & & & & & & \\
\hline 82 & WESTVILLE W D & WWD 4 & MRPAL & 38 & 43 & 45.884 & 22 & & & & & & \\
\hline 83 & WESTVILLE W D & WWD 6 & MRPAL & 38 & 43 & 5.277 & 22 & & & & & & \\
\hline
\end{tabular}


For additional information, write to:

U.S. Geological Survey Water Resources Division New Jersey District Mountain View Office Park 810 Bear Tavern Rd., Suite 206

West Trenton, NJ 08628

or visit our Web site at: http://nj.usgs.gov/ 